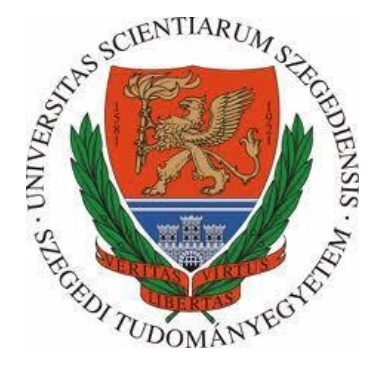

\title{
EXPERIMENTAL STUDY OF RADIOGENIC HEART DAMAGE USING IN VITRO AND IN VIVO ANIMAL MODELS
}

\author{
Ph.D. Thesis
}

\section{Laura Kiscsatári}

\author{
Department of Oncotherapy \\ University of Szeged, Faculty of Medicine
}

Supervisor:

Zsuzsanna Kahán MD, DSc

Department of Oncotherapy

University of Szeged

Szeged

2016 


\section{TABLE OF CONTENTS}

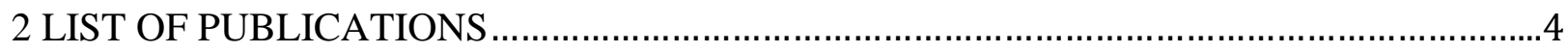

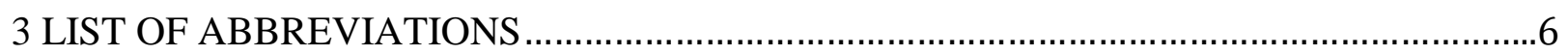

4 INTRODUCTION

5 AIMS

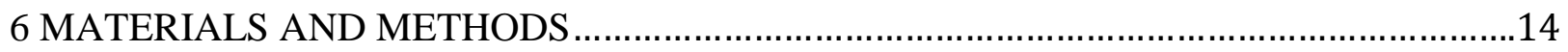

6.1 Experimental design and protocol of the in vitro study ............................................................14

6.1.1 Neonatal cardiac myocyte preparation, culturing and irradiation............................................14

6.1.2 Testing of GHRH agonist treatment.........................................................................15

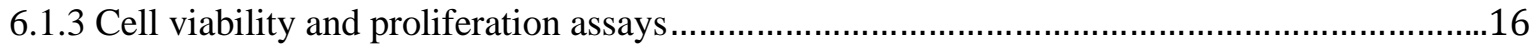

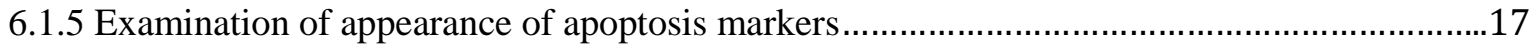

6.1.6 DHE staining for oxidative stress detection....................................................................17

6.2 Experimental design and protocol of the in vivo study ............................................................18

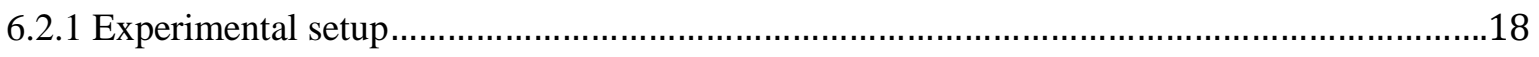

6.2.2 Selective heart irradiation...................................................................................19

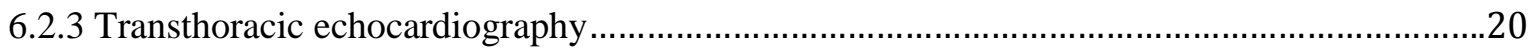

6.2.4 Measurement of GDF-15 and TGF-beta1 in plasma........................................................20

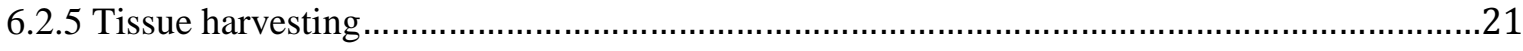

6.2.6 Histology and computerized image analysis of fibrosis in the heart.....................................21

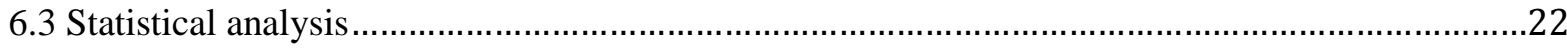

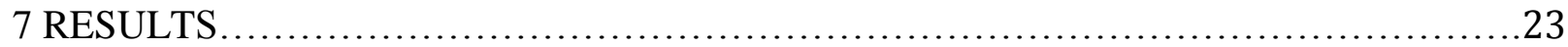

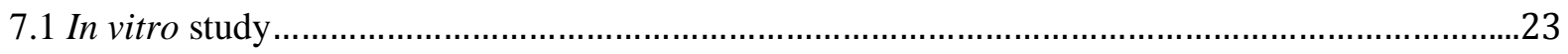

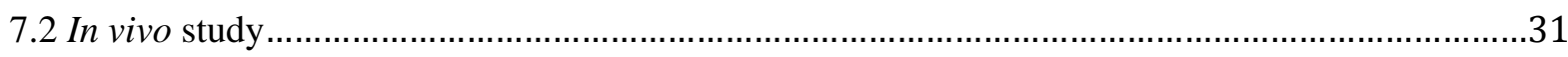

8 DISCUSSION

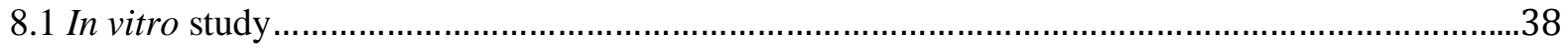

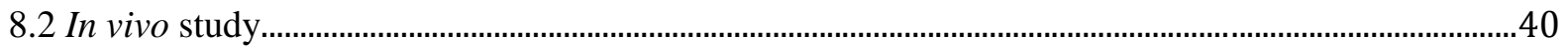

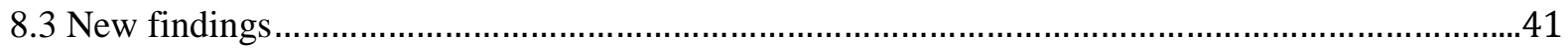

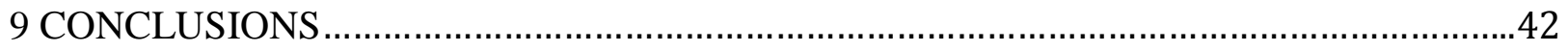

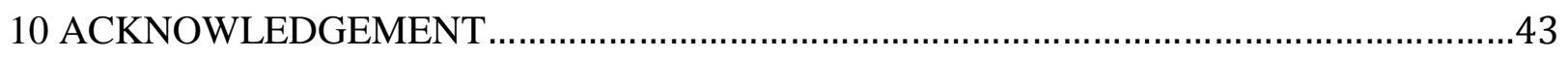




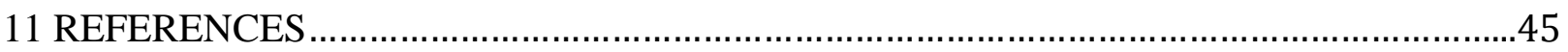

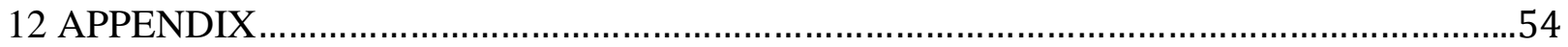




\section{LIST OF PUBLICATIONS}

2.1 List of scientific publications directly related to the subject of thesis

I. Laura Kiscsatári, Zoltán Varga, Andrew V Schally, Renáta Gáspár, Péter Ferdinandy, Gabriella Fábián, Zsuzsanna Kahán, Anikó Görbe

The protective effect of GHRH agonists against radiation-induced damage of neonatal rat cardiac myocytes

Pharmacol Res. 2016, 111:859-866.

IF: 4.816

II. Laura Kiscsatári, Márta Sárközy, Bence Kővári, Zoltán Varga, Nikolett Morvay, István Leprán, Hargita Hegyesi, Gabriella Fábián, Bálint Cserni, Gábor Cserni, Tamás Csont, Zsuzsanna Kahán

High dose radiation-induced heart damage in a rat model IN VIVO, 2016, 30:623-632.

IF: 0.832

Cumulative impact factor of papers directly related to the thesis: $\mathbf{5 . 6 4 8}$ 
2.2 Other full papers published during the Ph.D. fellowship

I. Fekete G, Újhidy D, Együd Z, Kiscsatári L, Marosi G, Kahán Z, Varga Z. Partial breast radiotherapy with simple teletherapy techniques. Med Dosim. 2015, 40: 290295. IF: 1.007

II. Kiscsatári L, Végváry Z, Nagy N, Széll M, Haracska L, Kahán Z. Kifejezett sugárkárosodás régiós emlőbesugárzás után. Magyar Belorvosi Archívum 2015, 685: 184-188.

2.3 Published conference abstracts of subject of the thesis

I. Kiscsatári L,Varga Z, Görbe A, Morvay N, Kővári B, Ferdinandy P, Leprán I, Kahán Zs. In vitro és in vivo állatmodellek a szív radiogén sugárkárosodásának vizsgálatára. Magyar Onkológia 2013, 57: (Klnsz.) 114-135.

II. Varga Z, Kiscsatári L, Marosi G, Varga L, Kelemen Gy, Kahán Zs. Egyedüli tumorágy besugárzás teleterápiával. Magyar Onkológia 2013, 57: (Klnsz.) 114-135.

III. Kiscsatari L, Varga Z, Gorbe A, Morvay N, Kovari B, LepranI, Ferdinandy P, Kahan Z. P689 Examination of radiation-induced heart damage using in vitro and in vivo animal models. Cardiovascular Research 2014, 103: S102-S141.

IV. Kiscsatári L, Varga Z, Gáspár R, Görbe A, Ferdinandy P, Gardi J, Kahán Z. A növekedési hormon- felszabadító hormon (GHRH) receptorok potenciális szerepe a radiogén szívkárosodás esetén. Magyar Onkológia 2015, 59: (Klnsz.) 169-170.

Total impact factor: 6.655 


\section{LIST OF ABBREVIATIONS}

AKT

ANOVA

AP-PA

AWTd

AWTs

BCA

BrdU

BSA

calcein-AM

cAMP

CT

DNA

DCFH-DA

D-PBS

E/e’

ECG

ELISA

ERK1/2

FBS

FS

GAPDH protein kinase B (PKB), also known as Akt,

analysis of variance

anterior-posterior-posterio-anterior

anterior wall thickness diastolic

anterior wall thickness systolic

bicinchoninic acid assay

5-bromo-2'-deoxyuridine

bovine serum albumin

calcein acetoxymethyl ester

cyclic adenosine monophosphate

computed tomography

deoxyribonucleic acid

dichloro-dihydro-fluorescein diacetate assay

Dulbecco's phosphate-buffered Saline

ratio of the early flow velocity (E) and the septal mitral annulus velocity $\mathbf{e}^{\prime}$

electrocardiogram

enzyme-linked immunosorbent assay

extracellular signal-regulated kinase $1 / 2$

fetal bovine serum

fractional shortening

glyceraldehyde 3-phosphate dehydrogenase 


\begin{tabular}{|c|c|}
\hline GDF-15 & growth differentiation factor- 15 \\
\hline $\mathrm{GH}$ & growth hormone \\
\hline GHRH & growth hormone-releasing hormone \\
\hline hGHRH & human growth hormone-releasing hormone \\
\hline HR & heart rate \\
\hline HRP & horseradish peroxidase \\
\hline HSL & hue, saturation, luminance \\
\hline IMRT & intensity-modulated radiotherapy \\
\hline IVCT & isovolumic contraction time \\
\hline JAK2/STAT3 & Janus kinase2/ Signal Transducer and Activator of Transcription3 \\
\hline LSD & least significant difference \\
\hline LVEDD & left ventricular end diastolic diameter \\
\hline LVESD & left ventricular end dystolic diameter \\
\hline LVOT PGmax & left ventricular outflow tract maximal pressure gradient \\
\hline LVOT vmax & left ventricular outflow tract maximal flow velocity \\
\hline NRVM & newborn rat ventricular myocytes \\
\hline pGHRHR & pituitary receptor of growth hormone-releasing hormone \\
\hline $\mathrm{PI} 3 \mathrm{~K}$ & phosphatidil-inositol-3-kinase \\
\hline PMMA & poly(methyl metacrylate) \\
\hline RGB & red, green, blue \\
\hline RIHD & radiation-induced heart disease \\
\hline RIPA & radioimmunoprecipitation assay lysis buffer \\
\hline ROS & reactive oxygen species \\
\hline SDS-PAGE & sodium dodecyl sulphate polyacrylamide gel electrophoresis \\
\hline SV & splice variants \\
\hline
\end{tabular}


SWTd septal wall thickness diastolic

SWTs septal wall thickness systolic

TGF- $\beta \quad$ transforming growth factor-beta 


\section{INTRODUCTION}

\subsection{Radiation-induced heart damage and clinical importance}

Radiotherapy is an essential part of anti-cancer therapy. Radiation-induced heart diseases (RIHD) including ischemic heart disease, congestive heart failure, electrical conduct defects and valve abnormalities are typically late consequences of radiotherapy, occurring many years or decades after treatment $[1,2]$. Substantial number of irradiated patients may suffer from late sideeffects, these develop after chest irradiation in childhood cancers, lung, esophageal or breast cancer or Hodgkin's lymphoma [3, 4]. These often-unattributed complications cause deterioration in quality of life of long-surviving patients, extra health care costs, and lead occasionally to fatal outcomes. Previous studies have described that the heart damage caused by irradiation is doserelated and only develops many years after the radiation treatment $[1,5,6,7]$. Although with development of modern radiotherapy techniques significantly reduce the dose to the heart, in many cases, the whole heart or a part of it still receives a dose adequate to cause RIHD.

\subsection{The pathomechanisms of radiation-induced heart disease (RIHD)}

Presentation and monitoring of the radiation sensitivity of the heart occurred first in the 1970s, but currently the heart is regarded as one of the most critical dose-limiting organs in radiation therapy. The development of RIHD is dose-dependent, and is more possible if radiation exposure occurs at a younger age $[8,9]$. Ionizing radiation may be harmful to virtually all of the cardiac structures, but micro- and macrovascular damage formation seem to be the most important responsible pathomechanism. The most important epidemiological data on the occurrence of radiogenic cardiovascular disease originate from breast cancer studies. Darby et al., analyzing the SEER database of more than 300,000 patients, found that among those who received adjuvant radiotherapy, the patients with left sided tumors had a significantly increased risk of cardiac death due to cardiovascular diseases or myocardial infarction, appearing 10 years after the irradiation, and increasing further thereafter [6, 10]. It seems possible, that the radiogenic damage of the macrovasculature of the heart occurs after the exposure of these structures to relatively high doses. Animal experiments revealed inflammatory and oxidative damage leading to the formation of typical atherosclerotic plaques [4, 11]. Radiation-induced diffuse myocardium changes include microvasculature abnormalities, degenerative 
cardiomyocyte and interstitial fibrotic changes. Such abnormalities may develop after even low dose radiation exposure, and can result in the deterioration of the heart's pump function or in cardiac conduction abnormalities [5]. Cilliers et al., investigated radiation-induced timedependent changes of the myocardium in Wistar rats [12]. Interestingly, the radiation induced structural changes of the endothelial cells and myocytes developed early after the irradiation, and were accompanied by a transitory depression of the mechanical function of the heart; 100-180 days after the irradiation, only interstitial inflammation and fibrosis were present. Radiation induces inflammatory responses, and activates senescence pathways; there is a need to test new agents that could prevent these cellular responses.

The study of the pathomechanisms of RIHD, the identification of its early predictors, and its prevention by the administration of protective agents are relevant research perspectives studied under both experimental and clinical research conditions [4, 13]. Although different experimental approaches have been tested to model the clinical scenario of RIHD, the results obtained so far are rather contradictory, and only few of the in vivo models applied selective heart irradiation [5]. Early experiments focused on radiation-induced pericarditis in rabbits and dogs achieved with relatively high dose and short observational time, a steep dose response was found between 15-20 Gy [5]. Most experience was collected in murine models, despite that in these species the different structures of the heart show less radiosensitivity than in larger animals. The characteristics of RIHD including dose tolerance, pathophysiological consequences, latency times, and pathomechanisms vary according to the breed. Using Wistar rats, Lauk et al. demonstrated ventilatory failure accompanied with pleural effusion that developed earlier and in a more severe form at a higher (i.e. 20-40 Gy) than a lower (<20 Gy) heart dose [14]. High-dose irradiation caused life-threatening radiation pericarditis, and the animals had to be sacrificed; no long-term follow-up results could be collected. However, ECG changes, arrhythmias and histological changes of the myocardium such as the degeneration and loss of cardiomyocytes, the development of interstitial fibrosis and the reduction of capillaries in the myocardium did not show clear dose-dependence [15]. Yeung et al., in Sprague-Dawley rats, >6 months after the delivery of a single dose of 30-50 Gy to the heart, experienced dose-dependent vascular damage and decreased cardiac output, but no or insignificant fibrosis [15]. Sharma et al., developed an image-guided irradiation technique in Sprague-Dawley rats, and after the delivery of 21 Gy to the heart, found myocardial degeneration and fibrosis [16]. 


\subsection{Acute inflammatory markers in RIHD}

In clinical practice, the signs and symptoms of RIHD develop many years after radiation exposure, early predictive markers would be useful. Transforming growth factor-beta (TGF-beta) and growth differentiation factor-15 (GDF-15) belong to the TGF-beta/bone morphogenetic protein (BMP) superfamily involved in the regulation of cell proliferation, differentiation, apoptosis, inflammation and tumorigenesis $[17,18,19]$. TGF-beta is a key cytokine implicated in the development of radiation injury of various tissues [20, 21]. In cardiovascular diseases, GDF15 has great potential as a biomarker $[17,18,22]$.

\subsection{Growth Hormone-Releasing Hormone (GHRH)}

Growth hormone-releasing hormone (GHRH) was first identified in humans as a hypothalamic peptide hormone which primarily regulates the production and release of pituitary growth hormone (GH) (Figure 1) [23]. Lately, the expression of GHRH has also been demonstrated in a series of normal and cancerous tissues [24]. The pituitary receptor of GHRH (pGHRHR) belongs to the class type-II G protein-coupled receptors [25], the binding induces the production of cAMP that triggers a series of intracellular signaling cascades. The presence of its splice variants (mainly SV1, less importantly SV2, SV3) has been demonstrated in a series of peripheral normal tissues and in a variety of cancers [26, 27, 28]. Stimulation of the GHRHR results in the activation of the ERK1/2, AKT, JAK2/STAT3, PI3K/AKT pathways [29]. Numerous experimental data support the autocrine-paracrine role of the GHRH system with beneficial effects on tissue regeneration. GHRH has been shown to promote survival and inhibit apoptosis in cardiomyocytes in vitro despite serum starvation or isoproterenol treatment [30]. KanashiroTakeuchi et al described that the expression and activation of pGHRHR after GHRH administration were demonstrated in both adult rat ventricular myocytes and in $\mathrm{H} 9 \mathrm{c} 2$ embryonic rat heart cells, which expressed pGHRHR [31].

GHRH prevented death of adult rat cardiac myocytes induced by serum starvation or by isoproterenol treatment, which was antagonized by antagonistic analog of GHRH, JV-1-36. These protective effects were mediated by the activation of the extracellular signal-regulated kinase (ERK)1/2 and phosphoinositide-3 kinase (PI3K)/Akt signaling pathways. Additionally, isolated rat hearts subjected to ischemia-reperfusion (I/R) injury were protected by the 
administration of GHRH before ischemia, which was abolished if co-administered with JV-1-36 [30]. Penna at al. demonstrated similar results in the isolated rat heart model; the administration of GHRH at the onset of reperfusion reduced the size of the infarct, and this effect was abrogated if JV-1-36 was co-administered (antagonistic analog of GHRH) [32].

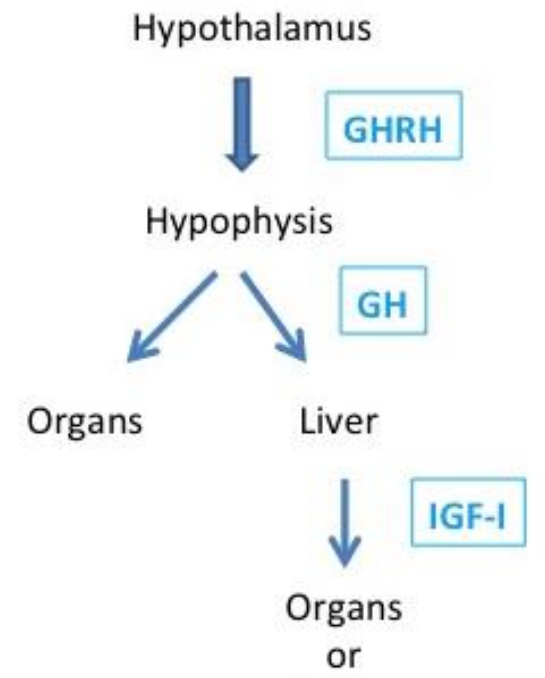

Tumor

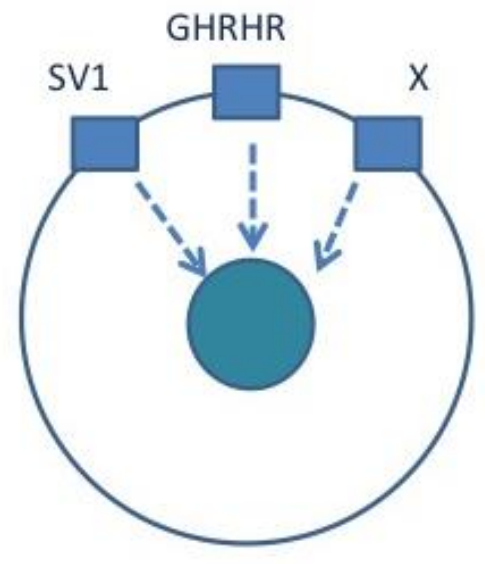

Autocrine and paracrine effect of GHRH

Figure 1. Possible mechanisms of stimulating effects of GHRH and GHRH agonists on healthy organs and tumors.

Kanashiro-Takeuchi demonstrated that the administration of the GHRH agonist, JI-38, reversed ventricular remodeling and enhanced functional recovery after myocardial infarction, while reducing experimental infarct size in rats [33]. These effects were absent if a GHRH antagonist was co-administered, or by treatment with GH only. These effects point to the role of a GHRHR-mediated mechanism. Following the demonstration of beneficial results of the JI class of agonistic analogs of GHRH in multiple fields, new classes of GHRH agonists have been developed with the ultimate goal of clinical use [34]. As noted some of them have been tested in the experimental myocardial infarct rat model, which confirmed the cardioprotective effects of GHRH agonists by measurement of infarct size and heart function [34, 35]. 


\section{AIMS}

The following aims were defined:

1. The development of an in vitro model appropriate for the study of the components and some pathomechanisms of RIHD and also for testing potential protective agents

2. The investigation of the possible role of GHRH and its receptors in irradiated cardiomyocytes

3. The in vitro study of the effects of GHRH and its agonistic analogs, JI-34 and MR-356, in both irradiated and unirradiated cardiomyocytes

4. The development of an in vivo model for the comprehensive study of RIHD after selective heart irradiation, with heart functional, imaging, biochemical and morphological endpoints 


\section{MATERIALS AND METHODS}

This investigation conformed to the National Institutes of Health Guide for the Care and Use of Laboratory Animals (NIH Pub. No. 85-23, Revised 1996) and was approved by the local ethics committee at the University of Szeged.

\subsection{Experimental design and protocol of the in vitro study}

In this series of experiments, the effects of irradiation and GHRH treatment on survival and various radiogenic stress-related biochemical changes of newborn rat ventricular myocyte (NRVM) cell cultures were assessed.

\subsubsection{Neonatal cardiac myocyte preparation, culturing and irradiation}

NRVM were isolated as previously described [36]. Briefly, newborn Wistar rats were disinfected with $70 \%$ ethanol and then killed by cervical dislocation. Hearts were excised and transferred to cold phosphate-buffered saline (PBS), $\mathrm{pH}$ 7.2. The ventricles were separated, minced gently by fine forceps and digested in $0.25 \%$ trypsin solution $(5 \mathrm{ml} / \mathrm{heart})$ at $37{ }^{\circ} \mathrm{C}$ for 25 minutes. The cell suspension was then centrifuged at $2000 \mathrm{RPM}$ at $4{ }^{\circ} \mathrm{C}$ for 15 minutes. Pellets were resuspended in growth medium (Dulbecco's MEM supplemented with $10 \%$ fetal bovine serum [FBS], $0.1 \%$ glutamine, $0.1 \%$ Antibiotic/Antimycotic solution) and plated onto 6-well plates to eliminate fibroblasts at $37^{\circ} \mathrm{C}$ for 90 minutes (pre-plating step). Cells of the supernatant were then re-plated onto fresh 6- and 96-well plates and flasks $\left(5 \times 10^{5}, 15 \times 10^{4}\right.$ and $4 \times 10^{6}$ cells/well, respectively). NRVM were supplied with $2 \mathrm{ml}, 150 \mu \mathrm{l}$ and $20 \mathrm{ml}$ per well growth medium with or without $10 \%$ FBS in 6-well, 96-well plates and flasks, respectively, and were incubated at $37{ }^{\circ} \mathrm{C}$ and $5 \% \mathrm{CO}_{2}$. The experiments were started 24 hours after plating. First, the cell cultures were irradiated with a linear accelerator (Siemens Primus, Siemens Medical Solutions, USA), $6 \mathrm{MV}$ energy photon beams with opposing field technique. To achieve a homogeneous dose distribution in the sample, $2 \mathrm{~cm}$ thick PMMA sheets were applied. (Figure 2) 


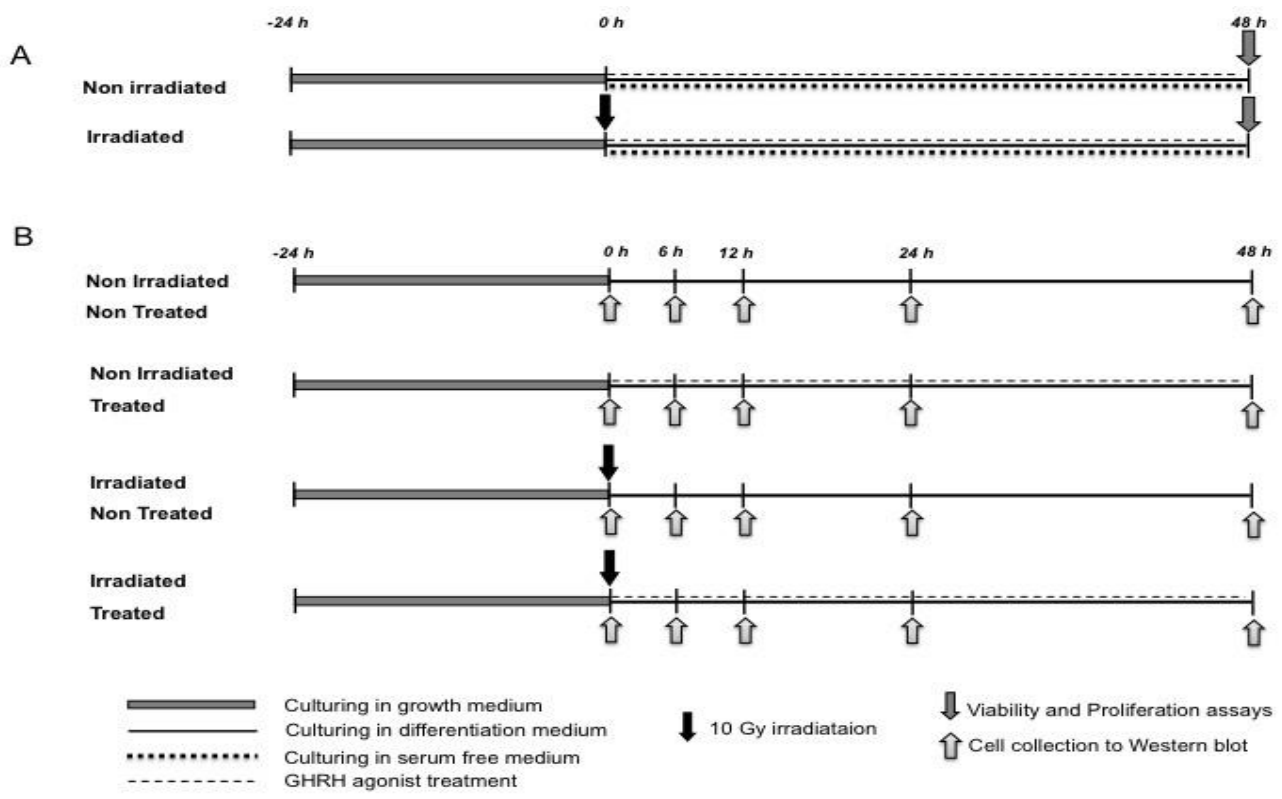

Figure 2 Experimental protocol. To assess the protective effects of GHRH agonists, NRVM were isolated and cultured from newborn rats. The 24-hour cultures were exposed to 10 Gy dose of radiation, and the effect was examined at different latency times $(0,6,12,24,48 \mathrm{~h})$. The cells were cultured in either in differentiation medium or serum-free medium and the toxicity of the radiation was evaluated with calcein fluorescence viability assay and BrdU proliferation assay. Western blot analysis was performed to detect the presence of GHRH receptors, before and after the irradiation.

\subsubsection{Testing of GHRH agonist treatment}

First, the effects of synthetic human GHRH (hGHRH) (Bertin Pharma, Montigny le Bretonneux, France) was tested at concentrations of 1, 10, 50, and $100 \mathrm{nM}$ in unirradiated and irradiated cell cultures. Next, GHRH agonists, JI-34 and MR-356, were studied both in unirradiated and irradiated cell cultures at concentrations of 1, 10, 50, 100 and $500 \mathrm{nM}$ in cultures with or without $1 \%$ FBS supplementation (for JI-34). Cell viability and proliferation assays were performed 48 hours thereafter. (Figure 2)

NRVM cultures maintained in FBS-supplemented medium were also studied for GHRHR expression and possible involved signaling pathways by Western blot analyses as follows: 1. nonirradiated, non-treated, 2. non-irradiated, JI-34-treated, 3. irradiated, non-treated, 4. irradiated and JI-34-treated; in these experiments, JI-34 was applied at the most effective concentration of 10 nM. Cells were collected 1 and 48 hours after the irradiation. 


\subsubsection{Cell viability and proliferation assays}

Both tests were performed following the respective experimental procedure (irradiation and/or treatment). For the assessment of cell viability, NRVM were incubated with $1 \mu \mathrm{M}$ calcein acetoxymethyl ester (calcein-AM, Sigma, St Louis, MO) at room temperature for 30 minutes. Fluorescence intensity was measured with a fluorescence plate reader (Fluostar Optima, BMG Labtech, Ortenberg, Germany) [37]. Cell viability was compared to that of vehicle control. Each plate contained non-irradiated columns serving as technical controls.

For the assessment of cell proliferation the NRVM cultures were incubated and labeled with $10 \mu \mathrm{l} /$ well 5-bromo-2'-deoxyuridine (BrdU) (Cell Proliferation ELISA, BrdU (colorimetric), Roche, Germany) labeling solution at $37{ }^{\circ} \mathrm{C}, 5 \% \mathrm{CO}_{2}$ for 20 hours. Then the labeling medium was removed, the cells fixed, and the DNA was denatured in one step with fix/denature solution. Then an anti-BrdU mouse monoclonal antibody was added followed by an HRP conjugated secondary antibody to detect the incorporated BrdU. The absorbance intensity was measured with a plate reader.

\subsubsection{Western blot analysis}

After the indicated time of incubation, cell cultures were washed with D-PBS and incubated for 5 minutes in homogenization buffer (1x RIPA supplemented with a protease and phosphatase inhibitor cocktail). Then cells were scraped, collected and sonicated with an ultrasound homogenizer for 10 seconds on ice. The homogenate was centrifuged at 11800 RPM, $4{ }^{\circ} \mathrm{C}$ for 10 minutes (Hettich Universal 320R Centrifuge, Andreas Hettich $\mathrm{GmbH}$ and Co., Tuttlingen, Germany); the supernatant was transferred into a concentrating tube (Amicon® Ultra4 Centrifugal Filter Units, $10 \mathrm{kDa}$ MWCO), and was centrifuged again at $6300 \mathrm{RPM}, 4{ }^{\circ} \mathrm{C}$ for 20 minutes. The concentrated sample was collected and stored at $-80{ }^{\circ} \mathrm{C}$.

Protein concentration was measured with bicinchoninic acid (BCA) assay (Pierce ${ }^{\mathrm{TM}} \mathrm{BCA}$ Protein Assay Kit, Thermo Fisher Scientific Inc., Waltham, MA USA) by reading the optical density at UV max of $560 \mathrm{~nm}$, and calculating automatically by the Anthos software. Twenty $\mu \mathrm{g}$ samples of protein were loaded on SDS-PAGE (10\%) followed by the transfer of proteins onto a 
nitrocellulose membrane ( $90 \mathrm{~V}, 1$ hour). Membranes were then blocked overnight at $4{ }^{\circ} \mathrm{C}$ in $1 \%$ bovine serum albumin (BSA). Membranes were incubated both with GHRH receptor antibody (1:1000, ab76263, Abcam Inc., Cambridge, MA) and GAPDH antibody (1:5000, Cell Signaling Technology, Danvers, MA) for 1.5 hours at room temperature in 1\% BSA (Cell Signaling Technology, Danvers, MA) and then anti-rabbit HRP secondary antibody $(1: 2000 ; 1: 10000$, Dako, Glostrup, Denmark) for 40 minutes. Membranes were then developed with an enhanced chemiluminescence kit (GE HealthCare, Little Chalfont, UK), exposed to X-ray film (Kodak, Rochester, NY, US), and scanned [38].

\subsubsection{Examination of appearance of apoptosis markers}

For the analysis of ERK and Akt, equal amounts of protein $(20 \mu \mathrm{g})$ were mixed with reducing $5 \times$ Laemmli buffer, loaded and separated in 4-20\% precast Tris-glycine SDS polyacrylamide gels (Bio-Rad Hungary Ltd., Budapest, Hungary). Proteins were transferred onto a polyvinylidene difluoride membrane (Bio-Rad Hungary Ltd., Budapest, Hungary) at $350 \mathrm{~mA}$ for $2 \mathrm{~h}$. Transfer was visualized with Ponceau staining (Sigma, St Louis, MO). Membranes were blocked with 5\% BSA (Santa Cruz Biotechnology, Inc., Heidelberg, Germany) in Tris-buffered saline containing 0.05\% Tween-20 (0.05\% TBS-T; Sigma, St Louis, MO) at room temperature for $2 \mathrm{~h}$. Membranes were probed with primary antibodies (dilution 1:1000) overnight at $4{ }^{\circ} \mathrm{C}$ (phospho-Akt [Ser473] - \#9271; Akt - \#9272; phospho-Erk1/2 [Thr202/Tyr204] - \#9106; Erk1/2 - \#9107; GAPDH - \#5174), and with corresponding HRP-conjugated secondary antibodies (Cell Signaling Technology, Danvers, MA) for $2 \mathrm{~h}$ at room temperature. Signals were detected with the chemiluminescence kit. Quantification was made by calculating intensity ratio by Image Lab 4.1 (Image $\mathrm{Lab}^{\mathrm{TM}}$ Software, Bio-Rad Laboratories, Inc., California, USA). Antibodies detecting phosphorylated epitopes were removed with Pierce stripping buffer (Thermo Scientific Labor Kft., Budapest, Hungary) before incubation with antibodies detecting the total protein.

\subsubsection{DHE staining for oxidative stress detection}

The presence of superoxide was detected with a plate reader using the oxidative fluorescent dye dihydroethidium (DHE) (Sigma St Louis, MO; D7008). Cell membranes are freely permeable to DHE that fluoresces red when oxidized to ethidium in the presence of superoxide. The presence of general reactive oxygen species (ROS) production was detected by 
dichloro-dihydro-fluorescein diacetate (DCFH-DA) assay (Sigma; D6883). Cardiac myocytes were rinsed with PBS, and then incubated with $10 \mu \mathrm{M}$ DHE or DCFH-DA at room temperature for $60 \mathrm{~min}$ in a dark chamber, after removing extra dye with D-PBS ( $\mathrm{pH} 7.4$ ), the fluorescence intensity was measured [39].

\subsection{Experimental design and protocol of the in vivo study}

In the animal experiments, the observation of the acute, subacute and late effects of a single shot of relatively large radiation dose was aimed at. Physiology, heart function, biochemical and morphology endpoints were defined.

The experiments were performed using male Sprague-Dawley rats weighing approximately 180-200 g. The animals were housed in three in individually ventilated cages (Sealsafe IVC system, Italy) and were maintained in a temperature-controlled room with $12 \mathrm{~h}$ : $12 \mathrm{~h}$ light/dark cycles throughout the study. Standard rat chow supplemented with 5\% fat (Innovo Kft., Gödöllö, Hungary) and tap water were supplied ad libitum throughout the experiment [40].

\subsubsection{Experimental setup}

Two preliminary experiments focused on dose finding and optimum timing of tests for the prespecified endpoints. In the first experiment, 5 groups of 2 animals each were selected, and 4 groups were irradiated with $20 \mathrm{~Gy}, 25 \mathrm{~Gy}, 30 \mathrm{~Gy}$ and $40 \mathrm{~Gy}$, respectively, while the control group remained unirradiated. The observation period lasted for 14 weeks after the irradiation. In the second experiment, 4 groups of 5 animals each were irradiated with $50 \mathrm{~Gy}$, and the observation time lasted for 14, 18, 22 or 26 weeks. An unirradiated group of the same size was observed for 26 weeks. In these preliminary experiments, feasibility was studied by means of weight gain, ventilatory symptoms and animal loss. Circulating cytokine tests and echocardiographies (at weeks 0, 3, 8, 10 and 26) were performed for orientation, and heart pathology was studied with special attention to fibrosis and other radiogenic abnormalities.

In the third experiment, the animals were divided into control and irradiated groups ( $\mathrm{n}=12$ each) (Figure 3). In the irradiated group, a single dose of $50 \mathrm{~Gy}$ was delivered to the whole heart. Body weight was measured every week in both groups. At weeks 0, 3, 12 and 19, cardiac morphology 
and function were assessed by transthoracic echocardiography and ECG (Figure 3). At weeks 0, 3 and 8, $1 \mathrm{ml}$ blood samples were carefully collected with $25 \mathrm{G}$ needles from the tail vein into heparinized Eppendorf tubes. Plasma was separated by centrifugation at 4460 RPM, 10 min, 4 ${ }^{\circ} \mathrm{C}$, and stored until measurements at $-70{ }^{\circ} \mathrm{C}$.

Despite the initial plan to follow up the animals for 24-28 weeks, at week 19, autopsy was carried out because of status deterioration, and the organs were removed for different examinations.

A

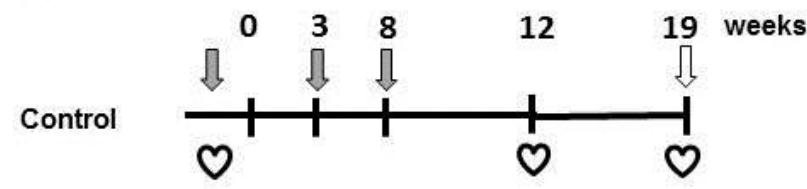

RT

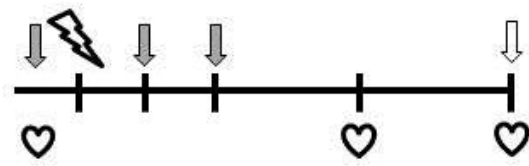

Echocardiography

\&. Single dose of 50 Gy irradiation

Blood sampling

Autopsy, histology
B

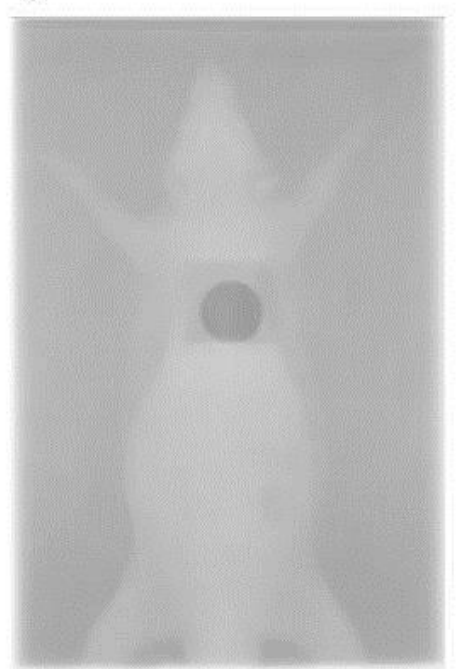

Figure 3 Experimental setup. Sprague-Dawley rats after sham or selective heart irradiation were examined by means of echocardiography, blood tests for circulating inflammatory cytokines and pathological studies focusing on the heart (A). A typical verification image of selective heart irradiation is shown (B).

\subsubsection{Selective heart irradiation}

Based on the CT morphology of the heart in 3 months-old Sprague-Dawley rats in the supine position, the irradiation was carried out with a single spherical field. According to the depth and transverse dose distribution, the $6 \mathrm{MeV}$ energy electron beam collimated with a $2 \mathrm{~cm}$ circular applicator was selected. The measurements were carried out using a water phantom with a pinpoint ionization chamber (PTW, Freiburg GmbH, Germany). Dose was prescribed as a mean 
dose to a $1 \mathrm{~cm}$ spherical volume $3 \mathrm{~mm}$ below the body surface.

The rats were anesthetized with sodium pentobarbital (Euthasol; ip. $40 \mathrm{mg} / \mathrm{kg}$; Produlab Pharma b.v., Raamsdonksveer, The Netherlands), then fixed in supine position to a flat surface couch. The radiation dose was delivered with a Primus linear accelerator (Siemens Healthcare GmbH, Erlangen, Germany) at a dose intensity of $5 \mathrm{~Gy} / \mathrm{min}$ if the appropriate position of the animal was proved by the verification film obtained with the radiation beam.

\subsubsection{Transthoracic echocardiography}

Echocardiography with a Vivid 7 Dimension ultrasound system (General Electric Medical Systems, Budapest, Hungary) using a phased array 5.5-12 MHz transducer (10S probe) was carried out at weeks 0, 12 and 19. The rats were anesthetized with $2 \%$ isoflurane (Forane, $100 \mathrm{ml}$, AESICA, Queenborough Limited Kent, UK), the chest was shaved, and the animal was placed in supine position onto a heating pad. Echocardiography was performed as described previously [41]. Moreover, maximal flow velocity and pressure gradient through the left ventricular outflow tract were assessed by continuous-wave Doppler across the aortic valve from the parasternal long axis view. Diastolic function was assessed using pulse-wave Doppler across the mitral valve from the apical four-chamber view. Early (E) and atrial (A) flow velocity as well as their ratio provide an indication of diastolic function. The septal mitral annulus velocity e' was assessed by tissue Doppler imaging as an early indicator of left ventricular diastolic dysfunction. The mean values of three measurements were calculated and used for statistical evaluation (EchoPac Dimension software; General Electric Medical Systems, Budapest, Hungary).

\subsubsection{Measurement of GDF-15 and TGF-beta1 in plasma}

Levels of plasma GDF-15 and TGF-beta1 protein were determined in blood taken from the rats the day before and 3, 8, 12 and 26 weeks (preliminary experiment) after the irradiation. Confirmatory measurement of GDF-15 concentrations was performed on samples taken in the third experiment before and 3 and 6 weeks after the irradiation. Cytokine levels were determined using the Quantikine Rat GDF-15/TGF-beta1 ELISA kit (R\&D Systems, Minneapolis, MN) according to the manufacturer's instructions. Optical densities were measured with fluorescent plate reader at $450 \mathrm{~nm}$ wavelength (Synergy HT, Biotec, USA). 


\subsubsection{Tissue harvesting}

In the third experiment, at week 19, rats were anesthetized with sodium pentobarbital, the chest was opened, and the heart was excised and placed in ice-cold Krebs-Henseleit buffer. After rapid cannulation of the aorta, the heart was perfused for 5 min at $37{ }^{\circ} \mathrm{C}$ according to Langendorff with oxygenated Krebs-Henseleit buffer as previously described [41, 42] in order to wash out the blood. After the ex vivo perfusion, the hearts were weighed, and a cross section of the whole heart at the ring of the papillae was cut and fixed in $10 \%$ buffered formalin for histological analysis. Following the removal of the heart, pleural fluid was collected from the chest, its volume was measured, and all the other organs were weighed.

\subsubsection{Histology and computerized image analysis of fibrosis in the heart}

Transverse cut sections of the formalin-fixed subvalvular area of the ventricles were embedded in paraffin. Five-micrometer-thick sections were stained with both conventional hematoxylin-eosin and picrosirius red for the detection of collagen [43]. In the preliminary experiments, picrosirius red staining of the sections was semiquantitatively evaluated by 2 independent pathologists blinded to the treatment received. Based on these results, in the third experiment, a computerized image analysis method was developed. Histological slides were scanned with a Pannoramic P250 scanner (3D-Histech, Budapest, Hungary), and digital images at magnification of x1.5 (whole transection area) and x20 (3 specified areas of the left ventricle: anterior, lateral and posterior wall, septum and lateral wall of the right ventricle) were captured. Care was taken to avoid medium-size vessels and their perivascular connective tissue sheet, the subepicardial and subendocardial areas. Digital images of the whole heart at x1.5 magnification fitting the screen were also captured. The saved images were analyzed with the help of an inhouse developed program which uses two simple color filters for determining the proportion of red in the heart. The first filter is used for detecting red portions of the picture. For each red, green, blue (RGB) pixel making up the image, the program calculates the color of the pixel in

hue, saturation, luminance (HSL) color space. The second filter excludes any white (empty) or light grey (residual dirt on the slide) pixel from further processing using simple RGB threshold. In this way, the program groups each pixel into one of two sets: pixels considered red (connective tissue and fibrosis), and pixels considered neither red, nor white, nor grey (i.e. green, corresponding to cardiac muscle). Dividing the number of elements in the first set by the number 
of elements in both sets gives the proportion of the connective tissue compartment of the heart.

\subsection{Statistical analysis}

All values are presented as mean \pm SEM. In the in vitro viability and proliferation studies one-way analysis of variance (ANOVA) followed by Fisher's or least significant difference (LSD) post-hoc tests or Dunnet's post-hoc tests were used to evaluate differences between groups. In case of superoxide and ROS determinations two experimental groups were analyzed with the t-test. Western blot results were analyzed with two-way analysis of variance (ANOVA). In the in vivo study, the statistical analysis was performed using Sigmaplot 12.0 for Windows (Systat Software Inc, Chicago, Illinois, USA). Baseline and different follow-up data including body weight and echocardiographic parameters were compared by means of repeated measures two-way ANOVA among the control and irradiated groups. All other parameters were compared by unpaired t-tests between the control and the irradiated groups. $\mathrm{P}<0.05$ was accepted as statistically significant. 


\section{RESULTS}

\subsection{In vitro study}

To determine optimal experimental conditions, NRVM were exposed to various radiation doses, and viability was measured following varying latency times (Table I). A significant cell loss of 50\% was obtained after $10 \mathrm{~Gy}$ dose of radiation and latency time of 48 hours. This set of conditions was chosen and applied throughout all the experiments.

$\begin{array}{lllll}\text { Time after irrad. } & \mathbf{5 ~ G y} & \mathbf{1 0} \text { Gy } & \mathbf{1 5} \mathbf{~ G y} & \mathbf{2 0} \text { Gy } \\ 0 \mathrm{~h} & 100 \pm 2 & 98 \pm 2 & 95 \pm 2 & 96 \pm 3 \\ 24 \mathrm{~h} & 76 \pm 2 & 75 \pm 3 & 79 \pm 4 & 89 \pm 6 \\ 48 \mathrm{~h} & 63 \pm 2 & 50 \pm 2 & 43 \pm 1 & 44 \pm 1 \\ 72 \mathrm{~h} & 58 \pm 3 & 49 \pm 3 & 43 \pm 3 & 42 \pm 2 \\ 96 \mathrm{~h} & 71 \pm 7 & 78 \pm 8 & 53 \pm 3 & 49 \pm 3 \\ 120 \mathrm{~h} & 50 \pm 2 & 38 \pm 1 & 37 \pm 1 & 39 \pm 2\end{array}$

Table 1 Cell survival in function of irradiated NRVM. Cell survival in ratio to control (\%).

First, the effect of hGHRH was tested on cell viability and cell proliferation in unirradiated and irradiated NRVM cultures. hGHRH did not significantly influence cell survival as compared to control (Figure 4A and B). hGHRH was tested for its effect on cell proliferation via the BrdU incorporation assay. Cell proliferation of both irradiated and non-irradiated cells was slightly stimulated by hGHRH at a concentration of $50 \mathrm{nM}$ (Figure 4C). 


\section{A}

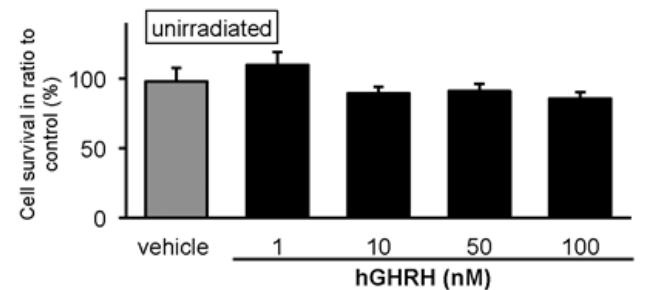

B

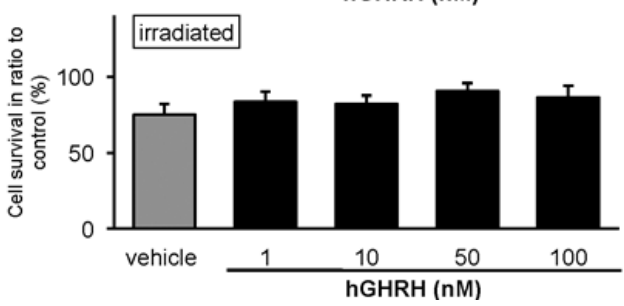

C

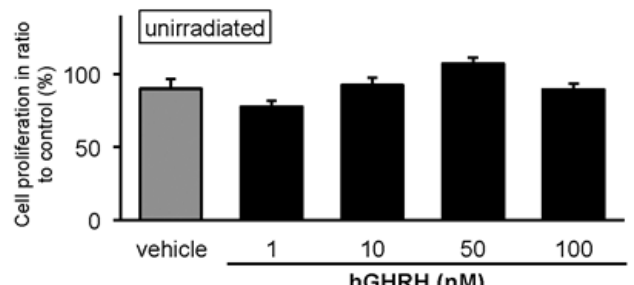

D

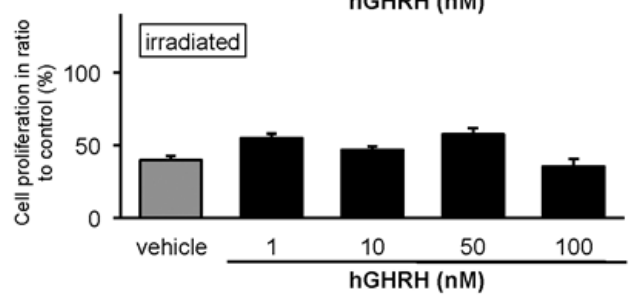

Figure 4 Viability of unirradiated (A) and irradiated (B) NRVM after hGHRH treatment (48h). The effects of hGHRH on the proliferation of unirradiated and irradiated NRVM are shown in panels $\mathrm{C}$ and $\mathrm{D}$, respectively. Data are expressed as mean $\pm \mathrm{SEM}$ in comparison to control $(100 \%) ; n=8-16$ in each group.

The effects of the GHRH agonists, JI-34 and MR-356, were first tested in unirradiated NRVM. The administration of JI-34 had no effect on cell viability at concentrations of 1-500 nM (Figure 5A). However, in irradiated cells, JI-34 showed a protective effect at concentrations of 10 and $100 \mathrm{nM}$ (Figure 5B). Anti-proliferative effect of JI-34 was detected at $50 \mathrm{nM}$ in unirradiated and at 1-50 $\mathrm{nM}$ in irradiated cultures (Fig 5C and D). 

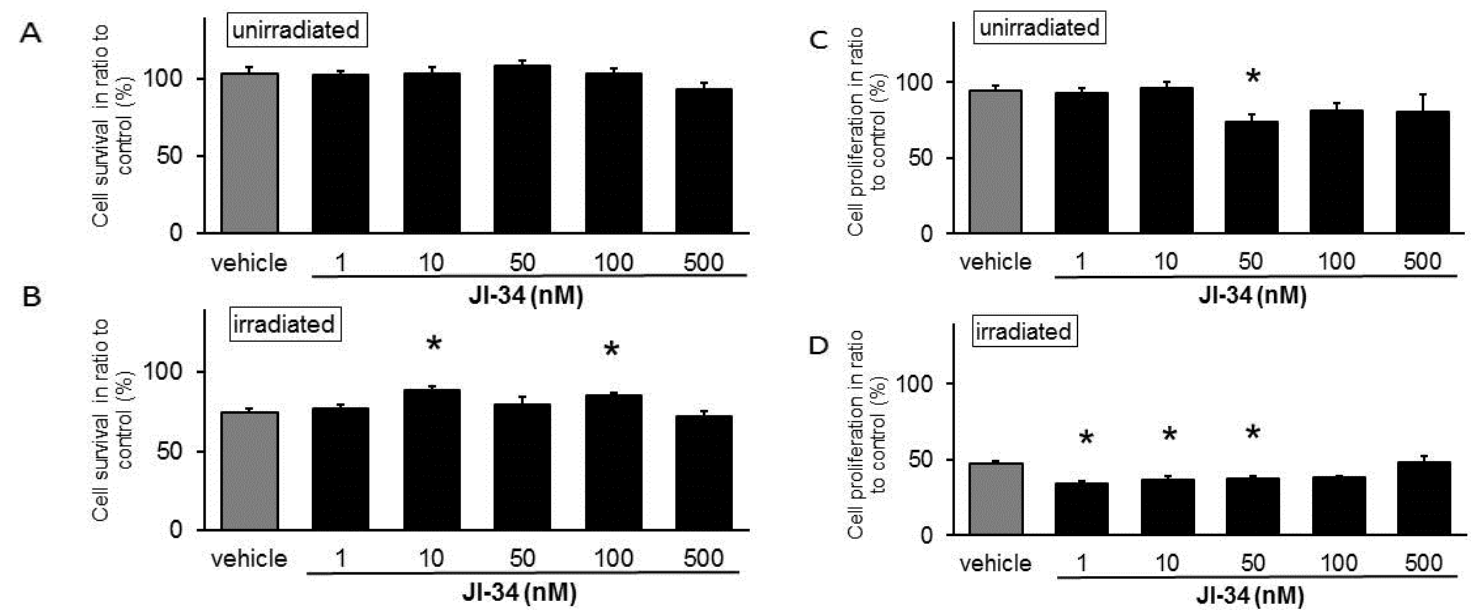

Figure 5 Viability of unirradiated (A) and irradiated (B) NRVM after JI-34 treatment (48h). Bromodeoxyuridine (BrdU) proliferation assay performed in unirradiated (C) and irradiated NRVM (D), $48 \mathrm{~h}$ after the treatment with JI-34. Data are expressed as mean $\pm \mathrm{SEM}$; in comparison to unirradiated untreated control $(100 \%)$. ${ }^{*} \mathrm{p}<0.05, \mathrm{n}=8-16$ in each group.

We have tested the same parameters under serum-deprived conditions to test the possible effects of the absence of $1 \%$ FBS including the avoidance of the binding of the analogs to the plasma proteins. NRVM cultures maintained in serum-free medium for 2 days contained roughly $50 \%$ less cells both in the irradiated and unirradiated plates (Figure 6A). Again, a strong protective effect of JI-34 was detected after irradiation, at concentrations of 10 and $100 \mathrm{nM}$ (Figure 6B).
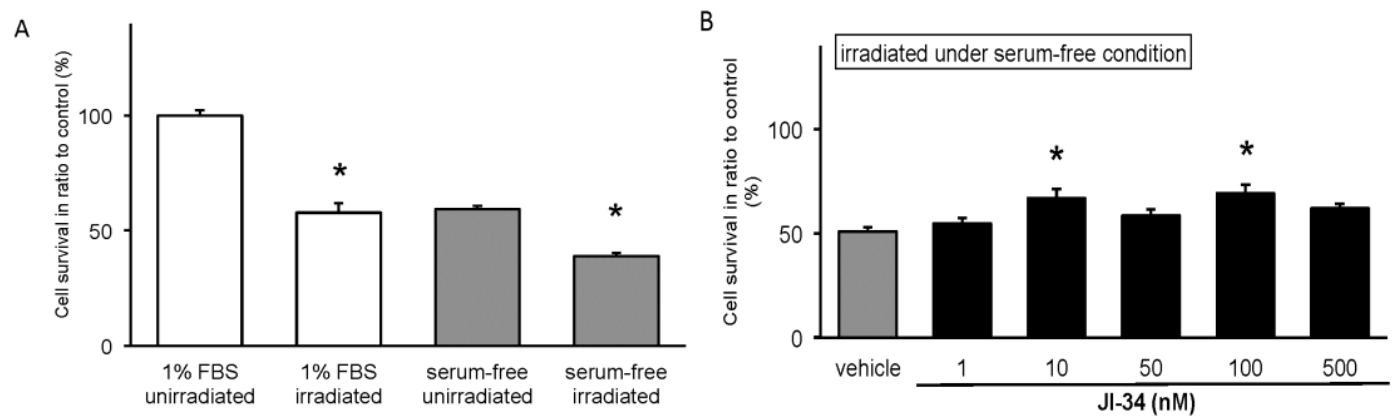

Figure 6 NRVM cell viability cultured with or without $1 \%$ FBS. Unirradiated and irradiated cultures were compared after $48 \mathrm{~h}$ of latency time (A). Viability of irradiated NRVM cells after JI-34 treatment, cultured without FBS supplementation; data are expressed as mean $\pm \mathrm{SEM}$; in comparison to control $(100 \%)$. $* \mathrm{p}<0.05, \mathrm{n}=8-16$ in each group (B). 
The GHRH agonist, MR-356, had no significant effect on cell survival in unirradiated NRVM cultures (Figure 7A), but prevented cell loss at a concentration of $500 \mathrm{nM}$ after irradiation (Figure 7B). No proliferative effect of MR-356 was detected in either the unirradiated or the irradiated cultures (Figure 7C and D).

A

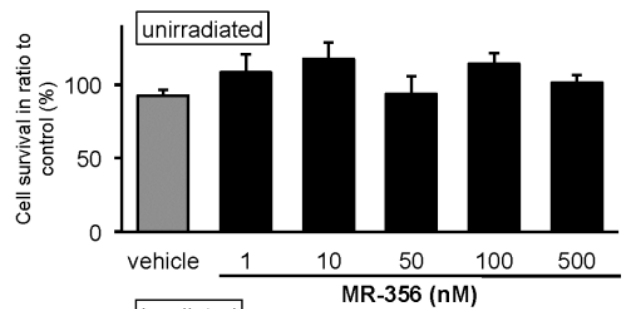

B

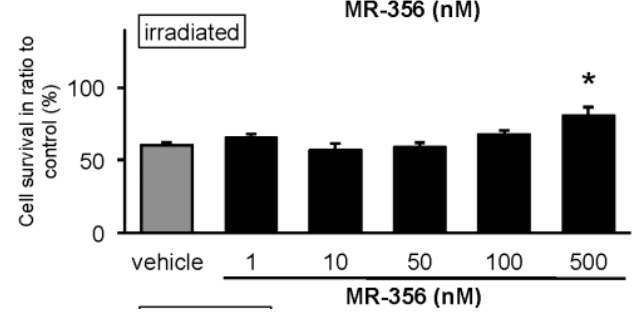

C

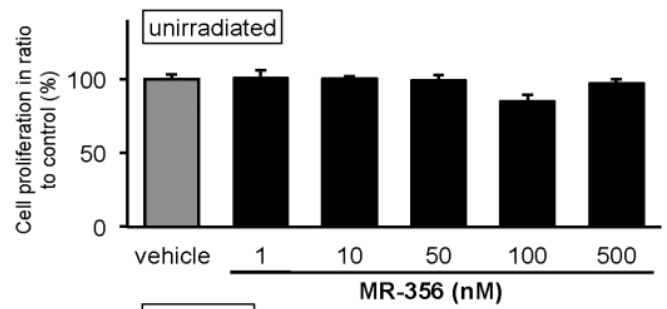

D

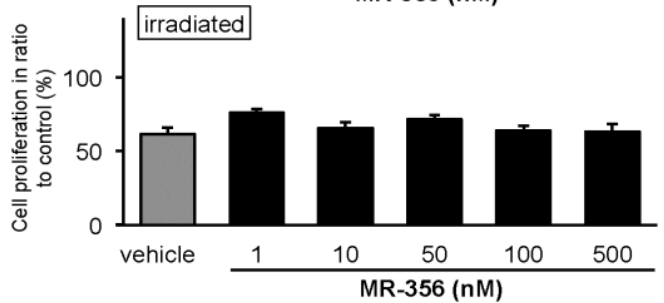

Figure 7 Viability of unirradiated (A) and irradiated (B) NRVM after MR-356 treatment. Bromodeoxyuridine (BrdU) proliferation assay performed in unirradiated $(\mathrm{C})$ and irradiated NRVM (D) $48 \mathrm{~h}$ after the treatment with MR-356. Data are expressed as mean $\pm \mathrm{SEM}$; in comparison to control $(100 \%){ }^{*} \mathrm{p}<0.05, \mathrm{n}=8-16$ in each group.

In order to investigate the expression of GHRHRs in NRVM at the protein level, Western blot analysis was performed using an antibody able to detect pGHRHRs. A $52 \mathrm{kDa}$ protein isoform was readily detected in the samples together with GAPDH used as internal control (Figure 8A). This $52 \mathrm{kDa}$ glycosylated GHRHR was expressed in both irradiated and unirradiated cells. The treatment of cells with JI-34, did not influence the expression of GHRHRs (probably due to optimal dose of agonist) in irradiated (Figure 8B) or unirradiated NRVM (Figure 8C). Irradiation caused significant decline in receptor expression after 48 hours. 


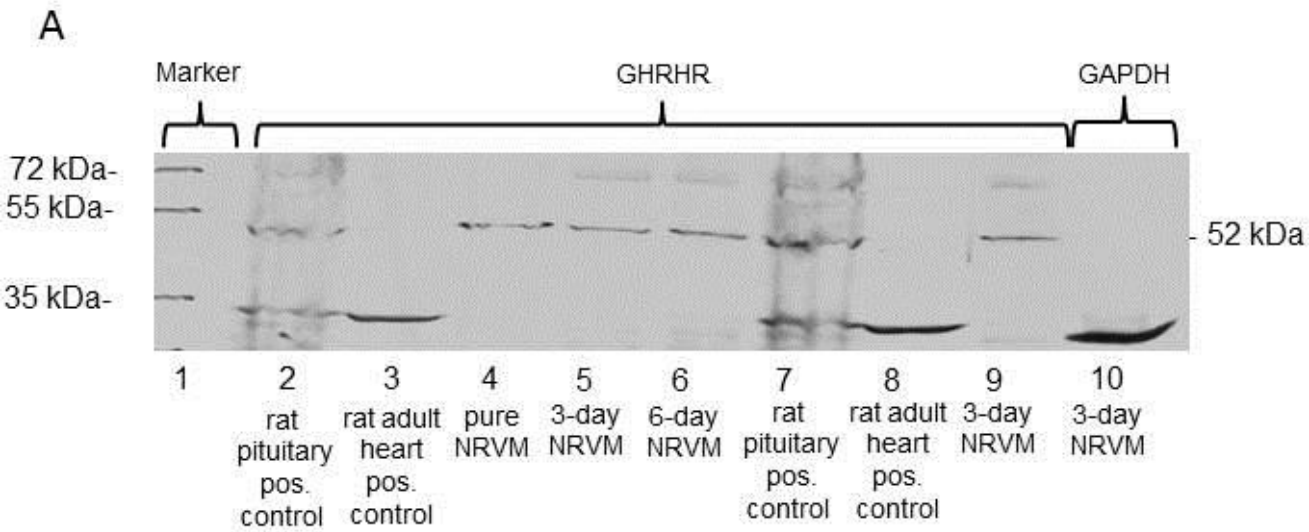

B
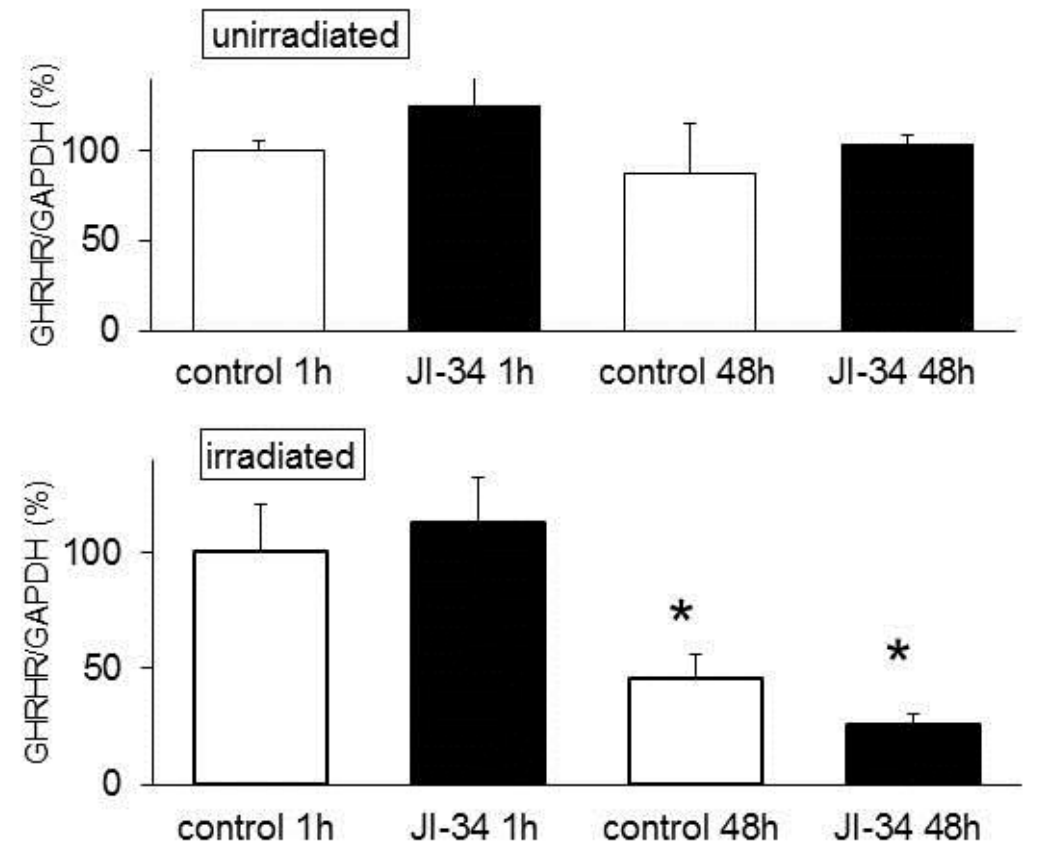

Figure 8 Western blot analysis: pGHRHR and GAPDH housekeeping gene expression (A). The expression of GHRHR was normalized to the GAPDH housekeeping gene in unirradiated (B) and irradiated (C) NRVM cultures. Western blots were performed both on untreated cells and cells treated with $10 \mathrm{nM} \mathrm{JI}-34$. Results are mean \pm SEM (expressed in $\%$ as compared to non-treated cells); $\mathrm{n}=6$ sample/group, ${ }^{*} \mathrm{p}<0.05$.

For further investigation of intracellular action of GHRH agonists, the activation of RISK/SAFE pro-survival kinases was tested. The phosphorylation ratio of ERK significantly increased after the irradiation with $10 \mathrm{~Gy}$, which was significantly attenuated by JI-34 treatment (Figure 9). 


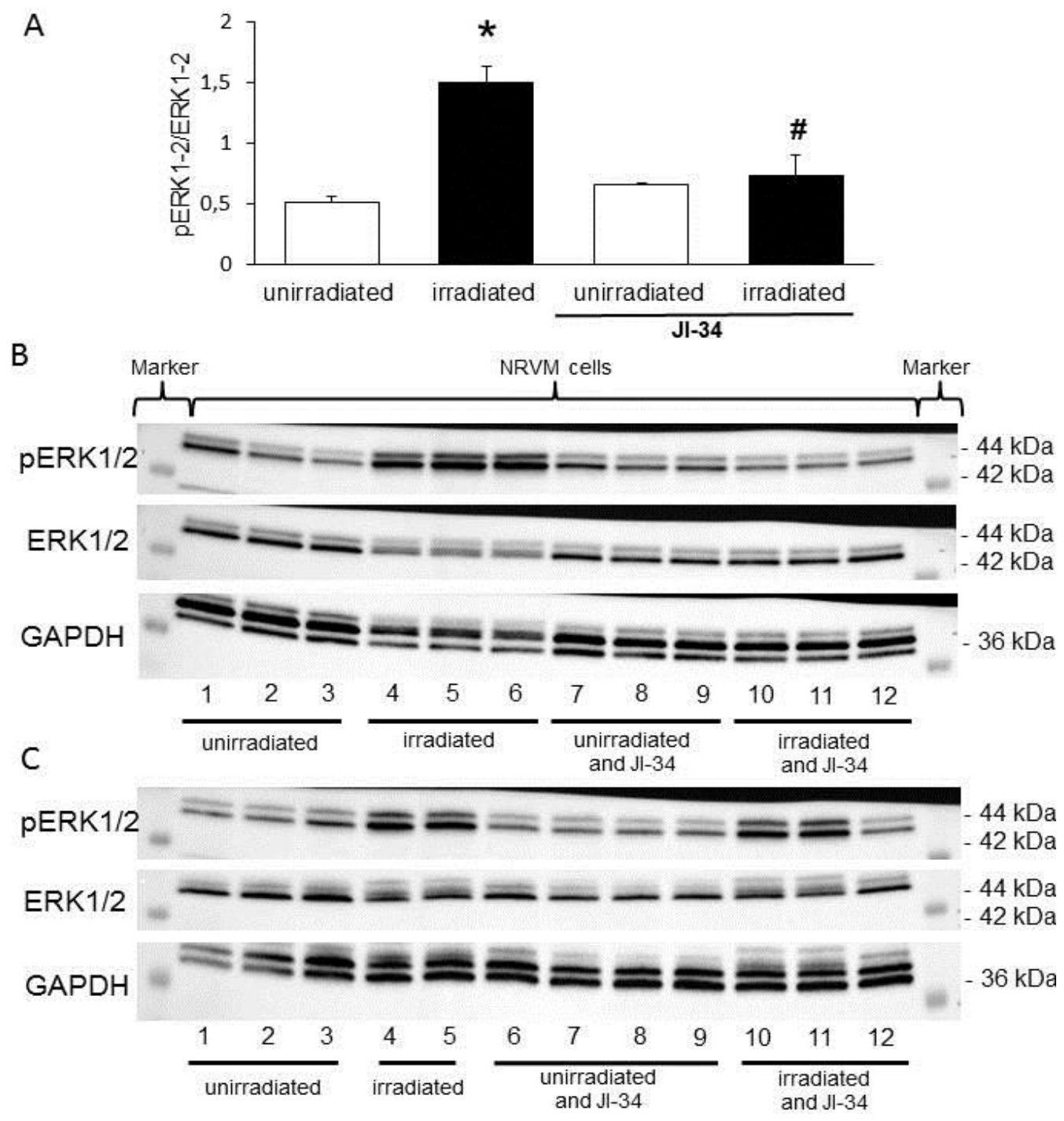

Figure 9 The expression of $\mathrm{pERK} / \mathrm{ERK}$ and the expression of GAPDH housekeeping gene in unirradiated and irradiated NRVM cultures. Western blots were performed both on untreated cells and cells treated with $10 \mathrm{nM}$ JI-34. Results are mean \pm SEM; ${ }^{*} \mathrm{p}<0.05$ as compared to unirradiated, $\# \mathrm{p}<0.05$ as compared to unirradiated, after JI-34 treatment. Panel B and C show two independent experiments. 
Likewise, the phosphorylation ratio of AKT significantly increased after the $10 \mathrm{~Gy}$ irradiation which was significantly attenuated after JI-34 treatment (Figure 10).

A

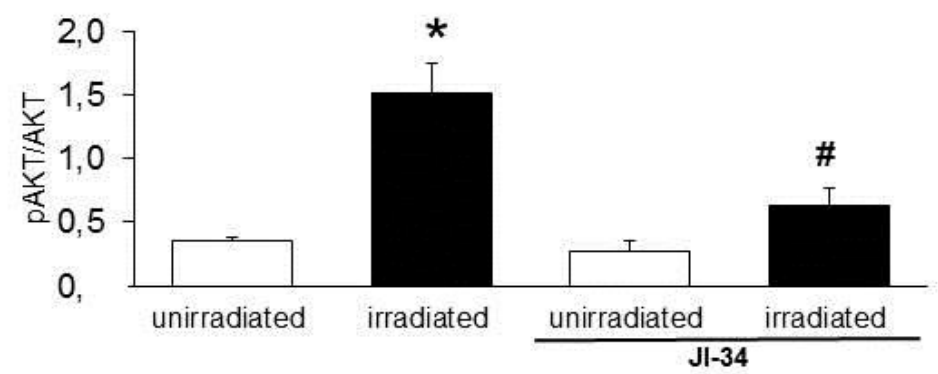

B
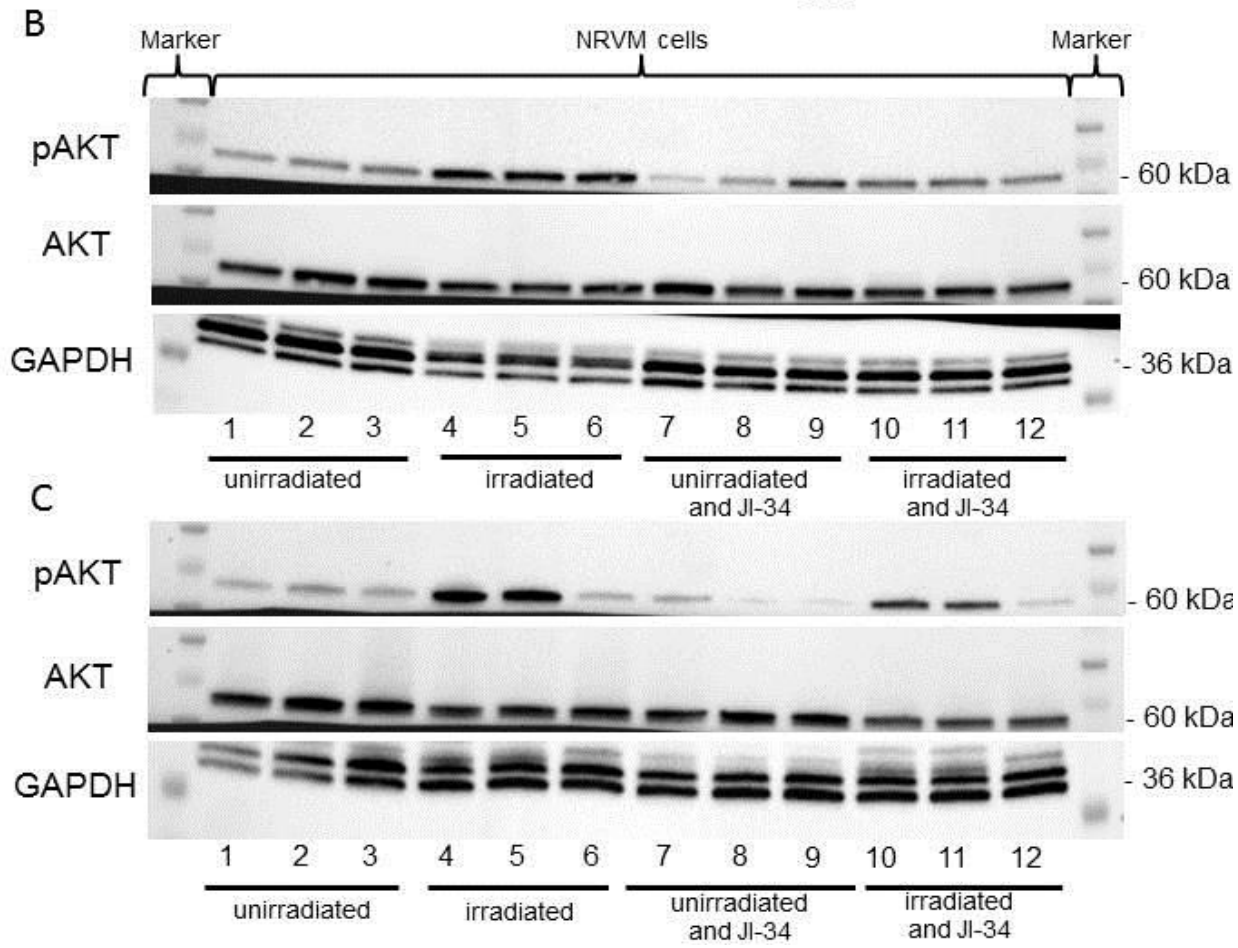

Figure 10 The expression of pAkt/Akt and the expression of GAPDH housekeeping gene in unirradiated and 10 Gy irradiated NRVM cultures. Western blots were performed both on untreated cells and cells treated with $10 \mathrm{nM}$ JI-34. Results are mean \pm SEM; *p<0.05 as compared to unirradiated values with the irradiated values, $\# \mathrm{p}<0.05$ as compared to initial unirradiated values with the JI-34 treated values. ${ }^{*} \mathrm{p}<0.05$ as compared to unirradiated, $\# \mathrm{p}<0.05$ as compared to unirradiated, after JI-34 treatment. Panel B and C show two independent experiments.

Next, JI-34 agonist was additionally tested for its possible effect on ROS production. Both the overall level of ROS and that of superoxide significantly increased $48 \mathrm{~h}$ after the irradiation. JI-34 treatment significantly decreased overall ROS production after irradiation, while MR-356 
decreased its level in both irradiated and unirradiated cultures. Both agonists decreased superoxide level significantly in irradiated cultures (Figure 11).
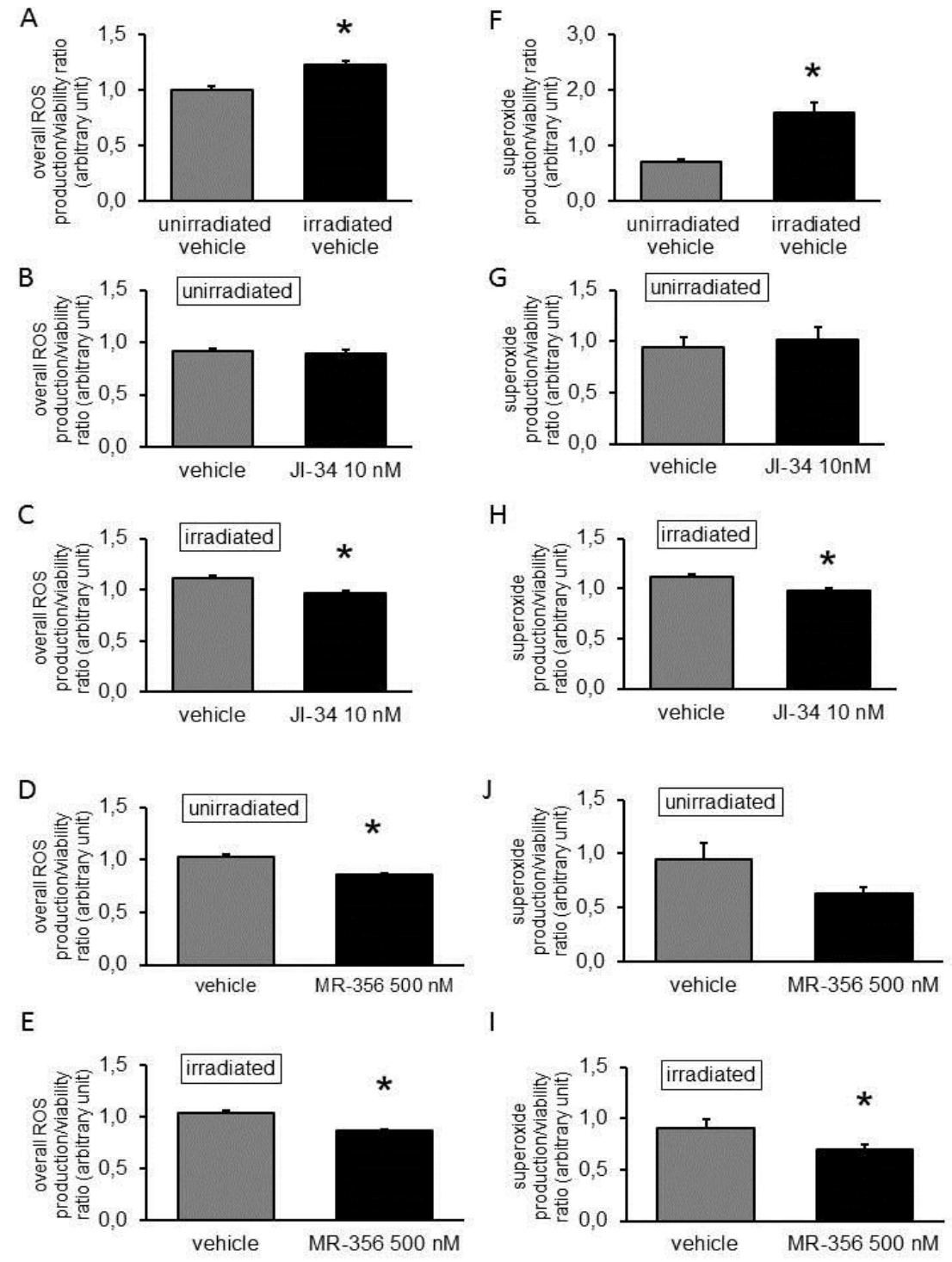

I

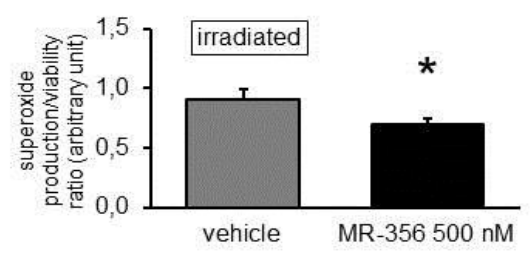

Figure 11 ROS production in ratio of viability (A) detected $48 \mathrm{~h}$ postirradiation. The effect of JI34 on ROS formation in unirradiated (B) and irradiated NRVM (C); the effect of MR-356 on ROS production in unirradiated (D) and irradiated cells (E). The superoxide level in ratio of viability detected $48 \mathrm{~h}$ after irradiation (F). The effect of JI-34 on superoxide levels in unirradiated $(\mathrm{G})$ and irradiated NRVM $(\mathrm{H})$; the effect of MR-356 on superoxide level in unirradiated $(\mathrm{J})$ and irradiated NRVM (I). Results are mean $\pm \mathrm{SEM} ;{ }^{*} \mathrm{p}<0.05$. 


\subsection{In vivo study}

In the first preliminary experiment, heart irradiation with doses of 20-40 Gy caused no symptoms or echocardiography changes during the 14 weeks of observation; also, no animal loss occurred despite the apparent growth retardation due to irradiation. The radiation dose of $50 \mathrm{~Gy}$, in the next experiment, caused tachypnea, abdominal breathing and heart functional changes with arrhytmias, but only after the observation time of 14 weeks. GDF-15 elevation occurred at weeks 3, 12 and 26, TGF-beta concentrations were continuously elevating during the observation period until the maximum value at week 12 (Figure 12). Four animals were lost during anesthesia for echocardiography, 1 at week 18 and 3 at week 22 . Hence, a radiation dose of $50 \mathrm{~Gy}$ and a followup time of a minimum of 24 weeks were chosen for the final experiment.

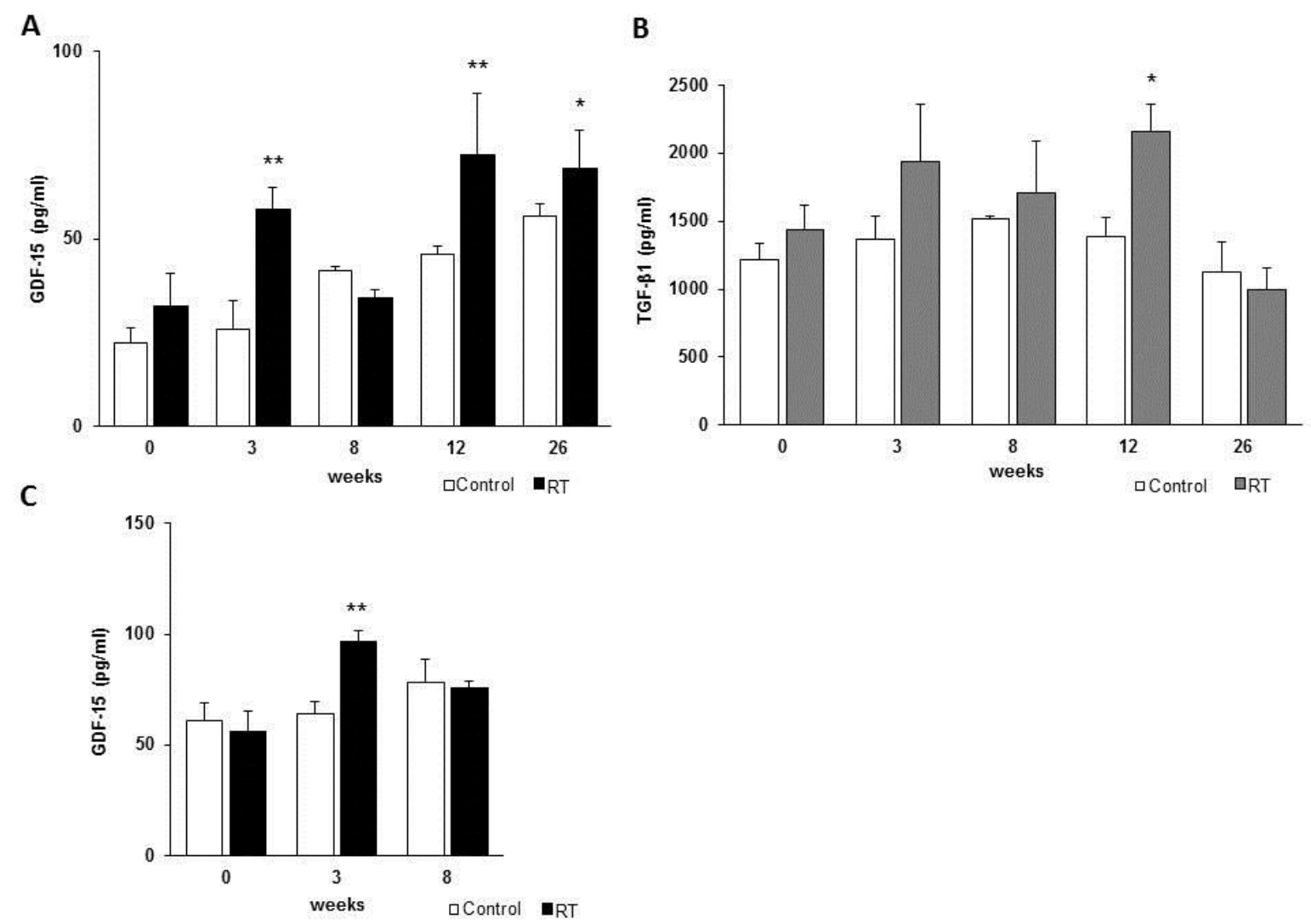

Figure 12 Plasma GDF-15 levels in 2 consecutive experiments (A and C) and plasma TGF-beta levels (B) in unirradiated controls vs. animals after selective heart irradiation. The measured data were analyzed by two way ANOVA and Holms-Sidak post hoc tests comparing data in the irradiated group with the control group (mean $\pm \mathrm{SEM},{ }^{*} \mathrm{p}<0.05$, ** $\mathrm{p}<0.01$ ), $\mathrm{n}=5$ /group. 
Although body weight constantly increased throughout the observation period, the irradiated animals showed significantly lower weight gain as compared to the control animals (Figure 13). After week 12, irradiated animals developed tachypnea and abdominal breathing and, after week 16, 2 animals in the irradiated group died. Due to the poor performance status of the irradiated animals, the experiment was terminated at week 19.

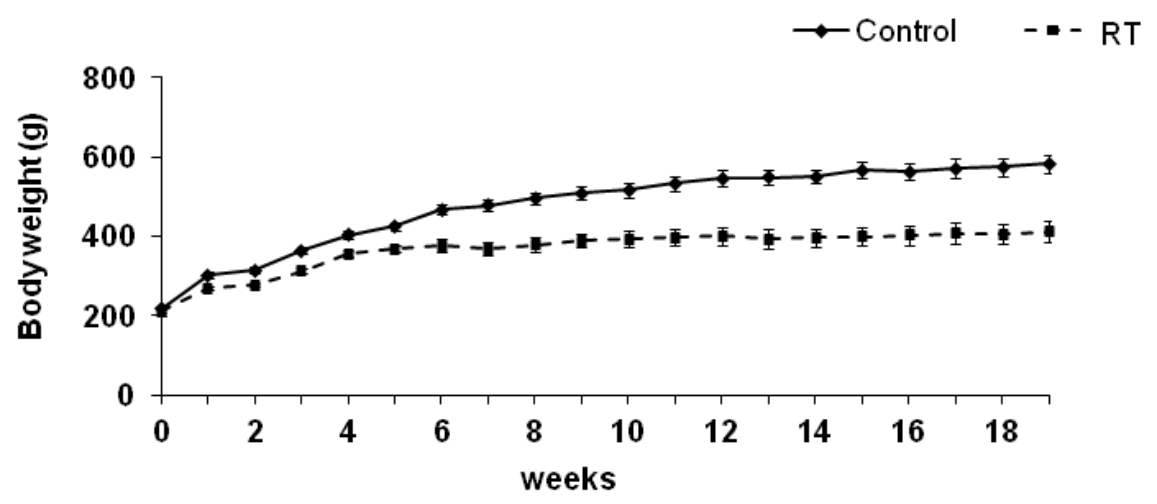

Figure 13 Body weight in unirradiated and irradiated animals. The measure data were analyzed by unpaired t-test comparing data in the irradiated group with the control group (mean $\pm \mathrm{SEM}$, $\mathrm{p}<0.05$ at all time points), $\mathrm{n}=10-12$ /group.

In the third experiment, transthoracic echocardiography was performed at weeks 0,12 and 19. Left ventricular systolic and diastolic anterior wall thickness in the irradiated rats was increased at weeks 12 and 19 as compared to both the baseline values and that in the control animals (Figures 14A and 15). 

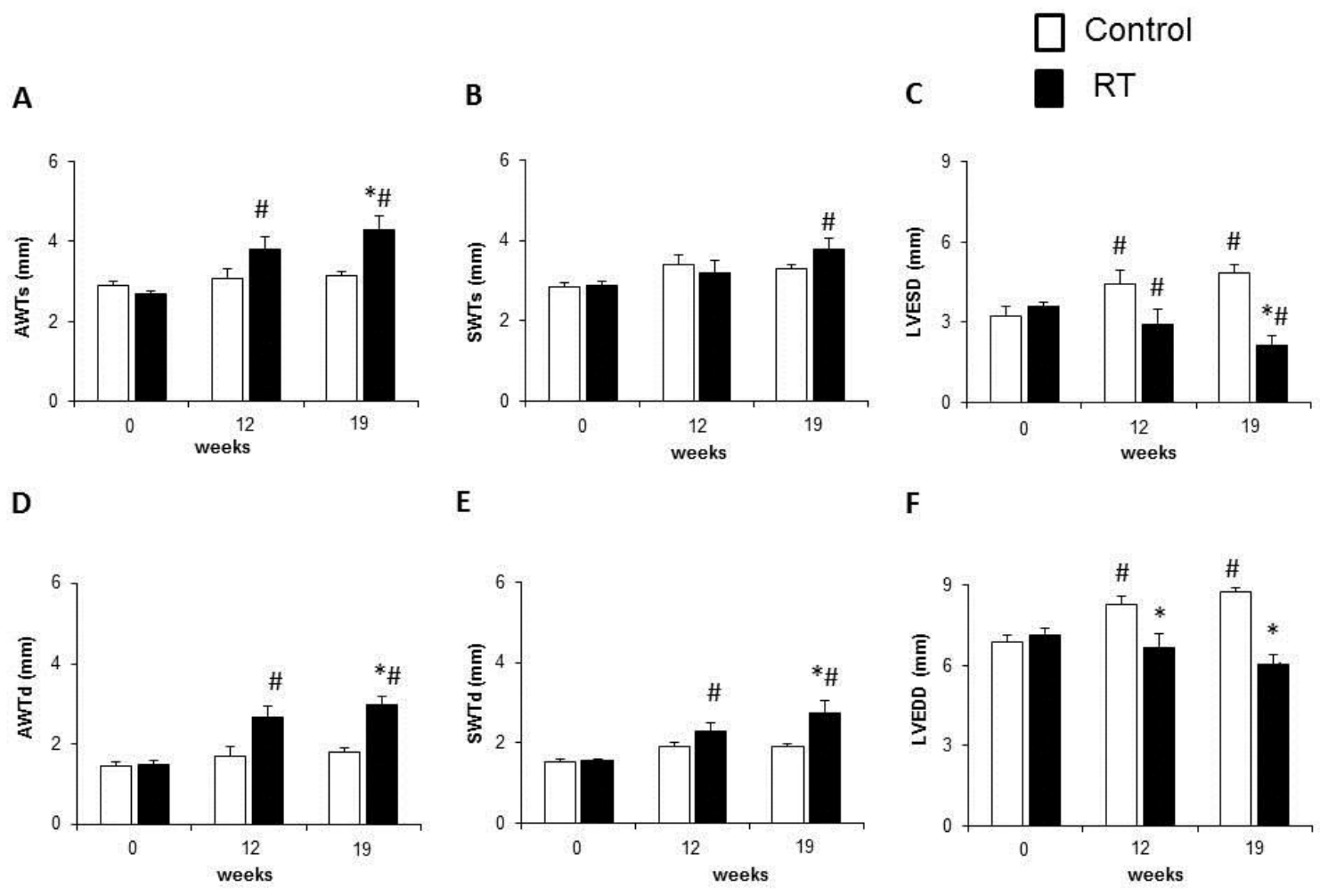

Figure 14 Left ventricular morphology as assessed by echocardiography. The parameters were analyzed by two way ANOVA and Holms-Sidak post hoc tests comparing data in the irradiated group with the control group (mean $\pm \mathrm{SEM}, * \mathrm{p}<0.05$ as compared to control group within the same time point, $\# p<0.05$ as compared to initial values within the same group), $n=10$-12/group.

Likewise, in irradiated rats, diastolic septal wall thickness was increased at week 19 as compared to the initial values or to the control group. While left ventricular end systolic and end diastolic diameters increased by time in control rats indicating normal heart growth, these parameters in the irradiated rats failed to increase or decreased, thus indicating retarded heart growth (Figure 14C). Increased anterior and septal wall thickness and decreased left ventricular diameters of the irradiated hearts point to the presence of left ventricular hypertrophy (Figures 14C and 15). Echocardiography performed at week 19, in addition, indicated the presence of arrhythmias. 
A

Control

week 0

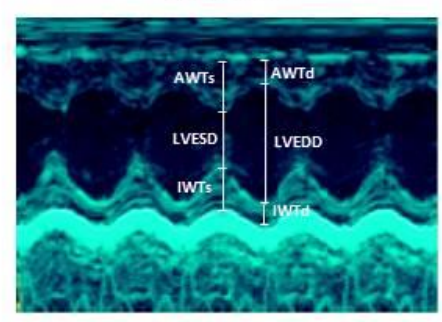

D

RT

week 0

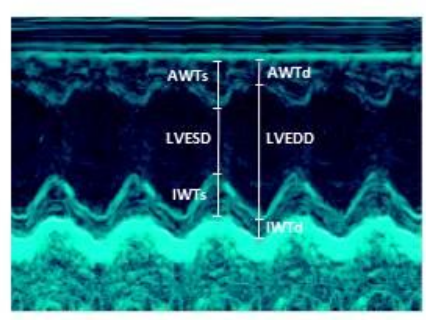

B

Control

week 12

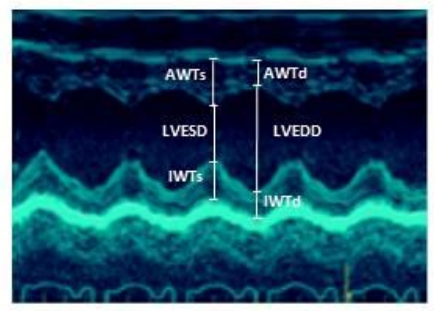

E
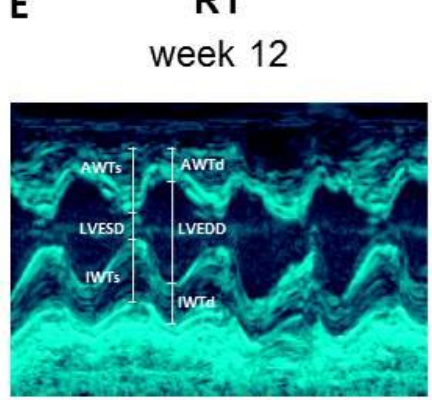

C Control

week 19

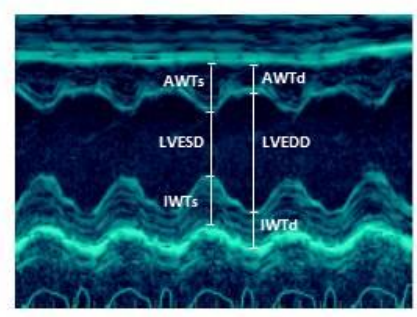

F

RT

week 19

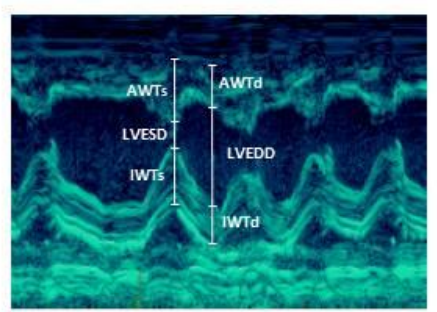

Figure 15 Representative M-mode echocardiographic images in cross section. Anterior wall, left ventricular diameters and inferior wall in systole and diastole represent 5 cardiac cycles at week 0,12 and 19 in a control and in an irradiated animal.

Irradiated animals demonstrated increased fractional shortening as compared to controls, at week 19 (Figure 16A). Physiological heart rate decrease, due to aging apparent in control rats, was lacking in irradiated animals (Figure 16B). Isovolumic contraction time was significantly increased in irradiated animals at weeks 12 and 19 as compared to the baseline or to that in control rats at week 19 demonstrating impaired systolic function after irradiation (Figure 16C). Other systolic parameters, maximal flow velocity and pressure gradient through the left ventricular outflow tract were significantly decreased in the irradiated rats as compared to controls at weeks 12 and 19 (Figures 16D-E). The ratio of the early flow velocity $\mathrm{E}$ and the septal mitral annulus velocity e' was significantly increased in the irradiated rats as compared to the baseline values or to that of controls at week 19, indicating diastolic dysfunction (Figure 16F). 


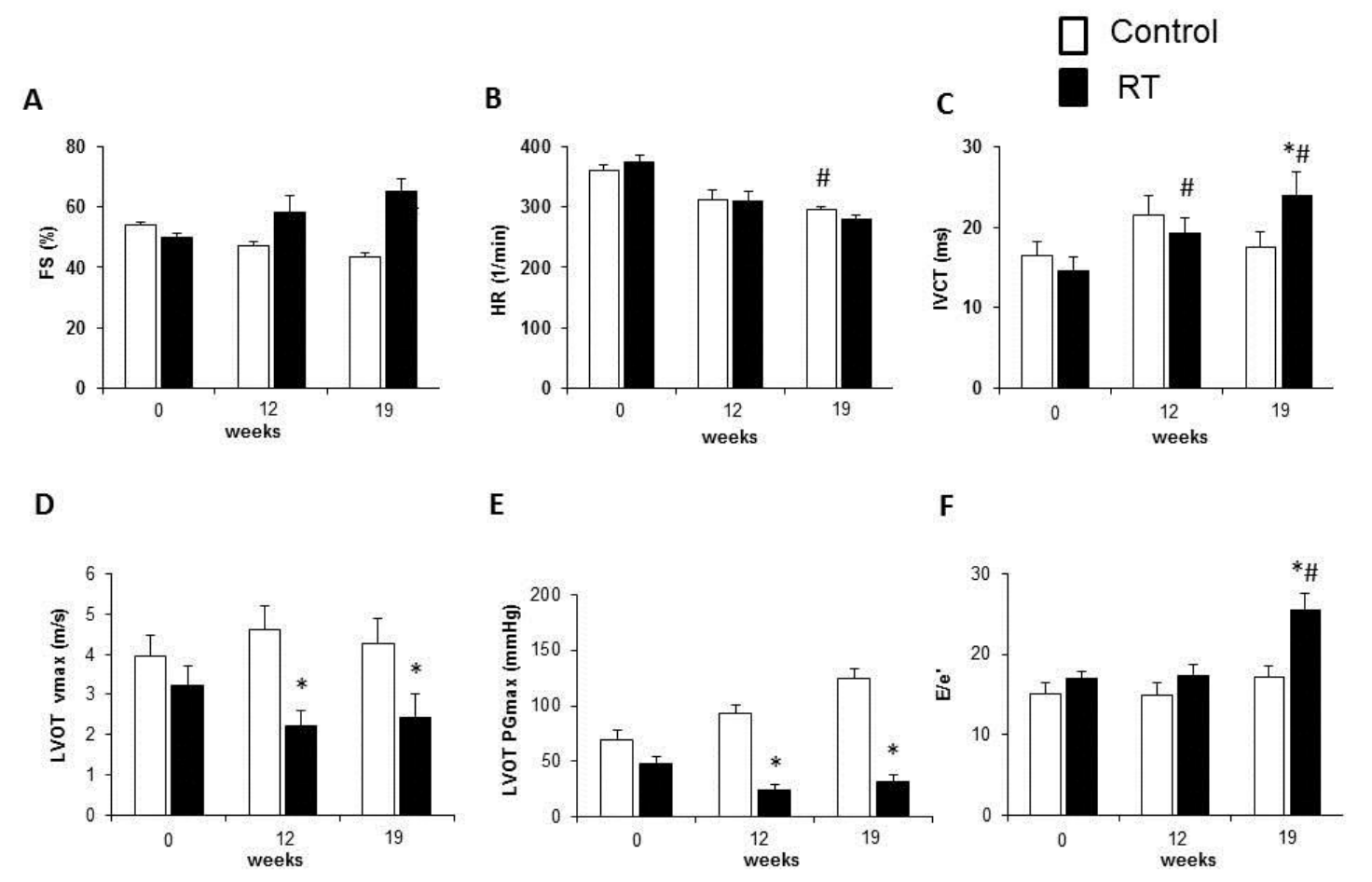

Figure 16 Left ventricular function as assessed by echocardiography. The parameters were analyzed by two way ANOVA and Holms-Sidak post hoc tests comparing data in the irradiated group with the control group (mean \pm SEM, $* p<0.05$ vs. control group within the same time point, \#p<0.05 vs. week 0 within the same group), $n=10-12$ /group.

The early peak of GDF-15, 3 weeks after the irradiation, was confirmed (Figure 12C).

At autopsy, the most common finding was the presence of extensive pleural fluid (11.3 \pm 1.7 $\mathrm{ml}, \mathrm{n}=10$ ) in irradiated animals. Neither abnormal macroscopic heart changes (including the large vessels, the valves, the coronary arteries etc.) nor sign of radiation pneumonitis or lung fibrosis were visible, confirming the selectivity of heart irradiation. In the irradiated group, the tibia length and the weight of various organs, including the heart, was significantly smaller than in the control group $(1.3 \pm 0.06$ vs. $1.7 \pm 0.07 \mathrm{~g}, \mathrm{p}<0.05)$.

Conventional morphological examinations of the pericardium, myocardium, vessels, perivascular, subendocardial, subepicardial areas and the coronary arteries, or the lungs, failed to reveal abnormalities in irradiated rats.

In the preliminary experiments, picrosirius red staining of the heart sections failed to detect 
fibrosis in animals irradiated with a dose of $<40 \mathrm{~Gy}$. In the $40 \mathrm{~Gy}$ heart irradiation group, slight but consistent fibrosis was visible after a follow-up of 26 weeks. In the final experiment, $50 \mathrm{~Gy}$ dose induced readily detectable collagen deposition appropriate for quantification after a followup time of 19 weeks. Our computer-assisted quantitative method indicated significant fibrosis in all parts of the heart (Figure 17). 


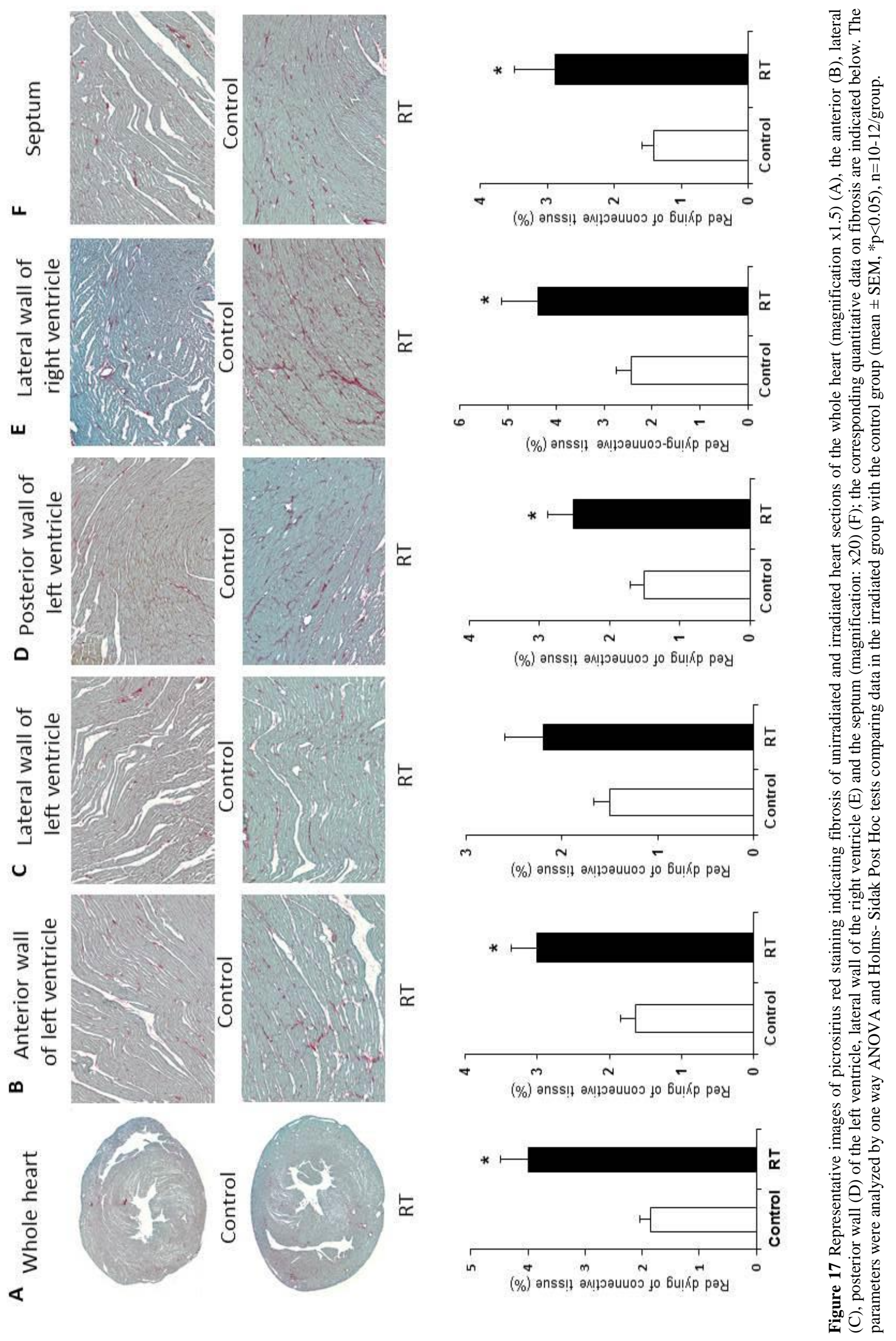




\section{DISCUSSION}

We aimed at developing reliable in vitro and in vivo (animal) models for the study of the effects of ionizing radiation on the heart and for testing potential radiation protective materials. Radiation-induced diffuse myocardium injury is time-dependent, developing after even a low radiation dose [5]. RIHD first starts with structural changes of the endothelial cells and myocytes inducing cardiac hypertrophy [5]. Later, interstitial inflammation and progressive fibrosis take place ultimately resulting in heart failure [44, 45]. Although much has been learned about the mechanisms of RIHD, the exact pathomechanisms have not been fully elucidated; furthermore, the identification of its early markers and the development of specific therapy for its prevention are needed $[2,46]$. The availability of tools to prevent or to alleviate the serious side effects of irradiation would be indispensable for safe radiotherapy.

\subsection{In vitro study}

This is the first demonstration that the agonistic analogs of GHRH, JI-34 and MR-356 of GHRH decrease the harmful effects of irradiation on NRVM cultures both under serumsupplemented and serum-free conditions. Apoptosis of cardiac myocytes is a common response to various stresses such as ischemia, nutrient deprivation, chronic catecholamine stimulation or radiation [30, 31, 47]. Radiation induces the apoptosis of cells by production of ROS, which results in DNA double strand breaks [48]. It has been shown that GHRH treatment prevents apoptosis induced by serum starvation or isoproterenol treatment in cardiac myocytes [30]. We have tested the effects of GHRH and its agonistic analogs, JI-34 and MR-356 in irradiated NRVM. JI-34 and MR-356, administered few hours after irradiation, increased cell viability.

The mechanism of cardiocytoprotection of GHRH agonists is not completely clarified, and probably depends on the system examined. The anti-apoptotic effects of GHRH agonists have been demonstrated in in vivo experimental infarcts in the rat. The chronic administration of the GHRH-agonist JI-38 upregulated the expression of the anti-apoptotic BCL2, while downregulated that of the proapoptotic $B A X$ gene, and increased the proliferation of cardiac precursor cells in experimental heart infarcts [35]. In a similar system, GHRH agonists reduced the expression of inflammatory and pro-fibrotic markers [31]. In H9c2 cardiomyoblasts cultured under serum-deprived condition, agonistic analogs of GHRH repressed the expression of a series 
of genes related to cardiac remodeling [31]. Some studies conclude to that GHRH or its agonistic analogs modulate the kinases included in the RISK and SAFE pathways [30, 32]. GHRH treatment prevented apoptosis induced by serum starvation or isoproterenol treatment in cardiac myocytes through the interaction with multiple signaling mechanisms involving the cAMP/protein kinase A, ERK 1/2 and PI3K/Akt pathways [30]. GHRH protected the rat heart from I/R-caused injury administered at reperfusion via activation of the RISK and SAFE pathways, as measured $20 \mathrm{~min}$ after the start of reperfusion [32]. The early activation of ERK 1/2 and Akt was detected by Granata, in serum-deprived isolated cardiac myocytes [30]. In our study, the post-irradiation administration of GHRH agonists also strongly affected the activation of the SAFE/RISK signaling pathways. Both JI-34 and MR-356 treatment significantly decreased phosphorylation of Akt and ERK after $48 \mathrm{~h}$ of latency time. Their protective effect may be explained by this phenomenon since irradiation induces the MAPK pathway and the phosphorylation of ERK via ROS formation [49]. In fact, our study indicates that the agonistic analogs of GHRH directly influence oxidative stress. ROS formation readily detectable $48 \mathrm{~h}$ after the irradiation was effectively reduced by the post-irradiation administration of JI-34 and MR356. The pretreatment of $\mathrm{C} 3 \mathrm{H}$ mice with the $\mathrm{GHRH}$ antagonist, JMR-132, caused a response dependent on the radiation dose of whole body radiation $[47,50]$.

The effects of GHRH or the agonistic analogs are mediated by the GHRHR. The administration of GHRH antagonists together with GHRH or its agonistic analogs abolished its protective effects on cardiomyocytes [30, 32]. We believe that GHRH and its receptors have physiological roles in the recovery from cell injury, and that the explanation for our findings in NRVM is the presence and function of the GHRHR. Granata et al. have demonstrated both the mRNA and protein expression of the pGHRHR in cardiac cells [30]. The pGHRHR has been detected in rat hearts by means of Western blotting, immunohistochemistry and ligand binding assay [35]. In consistence with these findings, we showed the presence of a $52 \mathrm{kDa}$ protein isoform of GHRHR with Western blotting; the expression of this protein declined by time in irradiated NRVM, irrespective of whether JI-34 treatment was applied. The difference the irradiation made may point to the role of the GHRH system in cell recovery after radiation injury. 


\subsection{In vivo study}

For the study of RIHD, an animal model for the selective irradiation of the heart and prevention of radiation-induced pneumonitis is essential. In our in vivo model using adult male Sprague-Dawley rats, we developed a selective heart irradiation technique, and studied the effects of both the dose and time of follow-up. We have studied the kinetics of inflammatory mediators, the heart function (ECG and transthoracic echocardiography), morphological changes, and intended to test new potential therapeutic agents that could influence radiogenic heart injury [51, $52]$.

The use of 50 Gy dose for heart irradiation provided drastic functional and morphological changes, some of them already present at 12 weeks. The time course of radiogenic, morphological and functional changes was similar to that in other studies [5, 3, 15]. Interstitial collagen deposition is thought to be progressive [5, 53, 54]; our experiments indicate that no abnormality occurs earlier than 5-6 months post-irradiation, even if a large dose is applied. Lately, we observed chronic cardiovascular and ventilatory insufficiency, partly due to pulmonary toxicity related to heart irradiation [55]. It is thought that the pathomechanism of RIHD in humans consists of progressive atherosclerosis of the coronary arteries due to endothelial damage, as well as diffuse injury of the myocardium [1,2]. The injury to the macrovasculature is difficult to test due to the absence of risk factors for coronary artery disease in experimental animals. We fed the animals with lipid-rich chow, but, despite the large radiation dose, no signs of macrovasculature changes were seen. For the detection of the loss of capillaries, no special staining was used. Conventional morphological methods, including hematoxylin and eosin or the Crossman trichrome stain of connective tissue, failed to reveal differences between unirradiated and irradiated animals' hearts even after the use of a dose of $40 \mathrm{~Gy}$. Using the picrosirius red/fast green staining method, after the delivery of $40 \mathrm{~Gy}$ and a follow-up time of 2226 weeks, there was slightly more apparent interstitial fibrosis in irradiated hearts. Since interstitial fibrosis is a major final end-point of radiogenic damage of all risk organs, a computerassisted quantitative method adequate for future radiobiology investigations was developed to measure this parameter.

Pleural fluid is a well-known consequence of heart irradiation due to - and explained by radiation pericarditis: the pericardium in rodents is interconnected with the pleural space and the 
origin of pleural fluid is thought to be pericardial fluid [5]. Pleural fluid, related to high-dose irradiation, was absent below the dose of $20 \mathrm{~Gy}$ both in our hands and the literature $[15,56]$. In our experiments, no histological abnormalities related to pericardial damage were seen, despite the fact that the pericardium was exposed to irradiation. We intended to find early markers that could predict consequent damage after heart irradiation. GDF-15 is related to a series of heart abnormalities [56-62]. We think that GDF- 15 elevation 3 weeks after the irradiation reflected an early stress-response, while its increase at weeks 12 and 26 was rather a consequence of heart failure. Fibrosis is a self-stimulating vicious circle resulting in the progressive nature of the process. The blockade of the key mediator TGF-beta may prevent or mitigate fibrosis [63]. In the present model, increased values of TGF-beta at week 12, predicted fibrosis in yet asymptomatic animals. In future experiments, GDF-15 and TGF-beta determination could serve as early parameters for testing radioprotective agents.

\subsection{New findings}

The agonistic analogs of GHRH, JI-34 and MR-356 reduce radiation-induced cell loss in in vitro cultured NRVM, the mechanisms of action include the attenuation of the phosphorylation ratio of ERK and AKT and the reduction of radiation-induced superoxide production. Based on these preliminary findings, the agonistic analogs of GHRH should be tested in vivo as potential protective agents against radiogenic heart damage.

An animal model for the comprehensive study of radiation heart damage has been developed. The identification of biochemical, functional and morphological parameters may serve as predictive markers or study endpoints in future experiments. Samples collected during the experiments provide instant possibility to further investigate the pathomechanisms of radiation damage. The model may be used for testing potential protective agents for the prevention of heart sequelae. 


\section{CONCLUSIONS}

Our in vitro experiments suggest a role for GHRH and its receptors in response to irradiation in cardiomyocytes. The agonistic analogs of GHRH, JI-34 and MR-356 exert protective effects in irradiated NRVM cultures; hence the study of GHRH analogs in in vivo experiments seems to be justified. Our NRVM radiobiology model provides appropriate system for testing other cardioprotective agents, too.

The reported selective heart irradiation in vivo rat model provides various readily measurable end-points for future radiobiology experiments. The short-term (circulatory inflammatory cytokines) and medium-term (heart functional abnormalities) objectives may be used to test protective agents in the same setting, while if comprehensive or long-term measures (fibrosis and other morphology endpoints) are needed, both the radiation dose should be lowered and the follow-up time might be extended. Ultimately, this radiobiology model should be used for testing cardioprotective agents including the agonistic analogs of GHRH. 


\section{ACKNOWLEDGEMENT}

At the end of my thesis I would like to thank all those people who made this thesis possible and provided an unforgettable experience for me.

I would like to express my sincere gratitude to my supervisor Professor Zsuzsanna Kahán for the continuous support of my PhD study and related research, for her patience, motivation, and immense knowledge. Her guidance helped me all the time during the research and writing of this thesis.

I would like to express my special thanks to Professor Andrew Victor Schally, for the opportunity to get acquainted with the GHRH topic, and that I could work with his invaluable peptides. Without partaking his essential recommendations, guidelines and personal experience from the beginning, this work could not have been accomplished.

I am immensely grateful to Dr. Gabriella Fábián and Dr. Zoltán Varga for their excellent leadership and supervision. Without of their high level of professional work and support this research would not have been possible. Thanks for the endless patience and that I could always rely on them!

I would like to thank to Professors László Dux, Professor Péter Ferdinandy, Drs. Anikó Görbe, and Tamás Csont, who provided me an opportunity to join their team, and who gave access to the laboratory and research facilities. I am also thankful to Dr. Márta Sárközy for her excellent scientific work in transthoracic echocardiography measurements and the evaluation of the experimental results. Without they precious support it would not have been possible to conduct this research. I am thankful to László Bodor and Róbert Motzwickler for their skillful assistance in the in vivo studies.

I am grateful to Professor Gábor Cserni, Dr. Bence Kővári and Bálint Cserni for their cooperation in the histopathological examinations and for the development of computerized image analysis techniques.

I would like to give my special thanks to Professor István Leprán for his advices at various stages during the in vivo project and for his kind interest in my work over several years. I am thankful to 
Dr. Nikolett Morvay for her work in the preliminary transthoracic echocardiography measurements. I am thankful to Anikó Deákné Tóth for her skillful assistance in the preliminary in vivo studies.

I owe sincere thanks also to Dr. Hargita Hegyesi for her excellent scientific advices and work in the GDF-15 measurements.

The members of the Department of Biochemistry have contributed immensely to my personal and professional development during my education. I thank my fellow labmates and friends for the stimulating discussions, for the sleepless nights and work-full weekends we were spending together before deadlines, and for all the fun we had in the past four years.

Particular thanks to all the Colleagues at the Department of Oncotherapy. Although they were very busy with their daily tasks, they have always been available to irradiate my cells...

I would never forget all the chats and beautiful moments I shared with some of my friends. They were fundamental in supporting me during these stressful and difficult moments.

Lastly, but most importantly, I wish to thank my grandmother, my parents and my loved sister for their unconditional love, care and support throughout my life; my gratitude to them is beyond words.

This work was supported by TAMOP-4.2.2.A-11/1/KONV-2012-0035 and TAMOP-4.2.2/B10/1-2010-0012. 


\section{REFERENCES}

1. Adams MJ, Hardenbergh PH, Constine LS and Lipshultz SE: Radiation-associated cardiovascular disease, Crit Rev Oncol Hematol 45:55-75, 2003.

2. Andratschke $\mathrm{N}$, Maurer $\mathrm{J}$, Molls $\mathrm{M}$ and Trott KR: Late radiation-induced heart disease after radiotherapy. Clinical importance, radiobiological mechanisms and strategies of prevention, Radiother Oncol 100:160-166, 2011.

3. Aleman BMP, Re D and Diehl V: The role of radiation therapy in patients with Hodgkin's lymphoma, Curr Hematol Malig Rep 2:151-160, 2007.

4. Stewart FA, Seemann I, Hoving S and Russell NS: Understanding radiation-induced cardiovascular damage and strategies for intervention, Clin Oncol (R Coll Radiol) 25: 617-624, 2013.

5. Schultz-Hector S: Radiation-induced heart disease: review of experimental data on dose response and pathogenesis, Int J Radiat Biol 61:149-160, 1992.

6. Darby SC, Ewertz M, McGale P, Bennet AM, Blom-Goldman U, Brønnum D, Correa C, Cutter D, Gagliardi G, Gigante B, Jensen MB, Nisbet A, Peto R, Rahimi K, Taylor C and Hall P: Risk of ischemic heart disease in women after radiotherapy for breast cancer, $\mathrm{N}$ Engl J Med 368: 987-998, 2013.

7. Gupta D, Pun SC, Verma S and Steingart RM: Radiation-induced coronary artery disease: a second survivorship challenge? Future Oncol 11: 2017-2020, 2015.

8. Schultz-Hector $\mathrm{S}$ and Trott KR: Radiation-induced cardiovascular diseases: Is the epidemiologic evidence compatible with the radiobiologic data? Int J Radiation Oncology Biol Phys 67:10-18, 2007. 
9. Stewart FA, Heeneman S, Te Poele J, Kruse J, Russell NS, Gijbels M and Daemen M: Ionizing radiation accelerates the development of atherosclerotic lesions in ApoE-Imice and predisposes to an inflammatory plaque phenotype prone to hemorrhage, Am $\mathrm{J}$ Pathol 168: 649-658, 2006.

10. Darby S, McGale P, Taylor CW and Peto R: Long-term mortality from heart disease and lung cancer after radiotherapy for early breast cancer: prospective cohort study of about 300000 women in US SEER cancer registries, Lancet Oncol 6:557-565, 2005.

11. Gabriels K, Hoving S, Seemann I, Visser NL, Gijbels MJ, Pol JF, Daemen MJ, Stewart FA and Heeneman S: Local heart irradiation of ApoE(-I-) mice induces microvascular and endocardial damage and accelerates coronary atherosclerosis, Radiother Oncol 105:358$364,2012$.

12. Cilliers GD, Harper IS and Lochner A: Radiation induced changes in the ultrastructure and mechanical function of the rat heart, Radiother Oncol 16:311-326, 1989.

13. Sridharan V, Tripathi P, Sharma S, Corry PM, Moros EG, Singh A, Compadre CM, HauerJensen $M$ and Boerma $M$ : Effects of late administration of pentoxifylline and tocotrienols in an image-guided rat model of localized heart irradiation, PLoS One 22;8:e68762, 2013.

14. Lauk S, Kiszel Z, Buschmann $\mathrm{J}$ and Trott KR: Radiation-induced heart disease in rats, Int J Radiat Oncol Biol Phys 11:801-808, 1985.

15. Yeung TK and Hopewell JW: Histological and physiological studies on rat heart following irradiation with single doses of X-rays, Br J Cancer Suppl 7:196-198, 1986.

16. Sharma S, Moros EG, Boerma M, Sridharan V, Han EY, Clarkson R, Hauer-Jensen M and Corry PM: A novel technique for image-guided local heart irradiation in the rat, Technol Cancer Res Treat 13:593-603, 2014. 
17. Chan D and Ng LL: Biomarkers in acute myocardial infarction, BMC Med 8:34, 2010.

18. Ago T and Sadoshima J: GDF15, a cardioprotective TGF-beta superfamily protein, Circ Res 98:294-297, 2006.

19. Kempf T, Eden M, Strelau J, Naguib M, Willenbockel C, Tongers J, Heineke J, Kotlarz D, Xu J, Molkentin JD, Niessen HW, Drexler H and Wollert KC: The transforming growth factor-beta superfamily member growth-differentiation factor-15 protects the heart from ischemia/reperfusion injury, Circ Res 98:351-360, 2006.

20. Grainger DJ, Mosedale DE and Metcalfe JC: TGF-beta in blood: A complex problem, Cytokine Growth Factor Rev 11:133-145, 2000.

21. Kahán Z, Csenki M, Varga Z, Szil E, Cserháti A, Balogh A, Gyulai Z, Mándi Y, Boda K and Thurzó L: The risk of early and late lung sequelae after conformal radiotherapy in breast cancer patients, Int J Radiat Oncol Biol Phys 68:673-681, 2007.

22. Xu J, Kimball TR, Lorenz JN, Brown DA, Bauskin AR, Klevitsky R, Hewett TE, Breit SN and Molkentin JD: GDF15/MIC-1 functions as a protective and antihypertrophic factor released from the myocardium in association with SMAD protein activation, Circ Res 98:342-450, 2006.

23. Ling N, Esch F, Böhlen P, Brazeau P, Wehrenberg WB and Guillemin R: Isolation, primary structure, and synthesis of human hypothalamic somatocrinin: growth hormonereleasing factor, Proc Natl Acad Sci USA 81:4302-4306, 1984.

24. Kiaris H, Chatzistamou I, Papavassilliou AG and Schally AV: Growth hormone-releasing hormone: not only a neurohormone, Trends Endocrinol Metab 22:311-317, 2011.

25. Martin B, Lopez de Maturana R, Brenneman R, Walent T, Mattson MP and Maudsley S: 
Class II G Protein-Coupled Receptors and Their Ligands in Neuronal Function and Protection, Neuromolecular Med 7:3-36, 2005.

26. Bellyei S, Schally AV, Zarandi M, Varga JL, Vidaurre I and Pozsgai E: GHRH antagonists reduce the invasive and metastatic potential of human cancer cell lines in vitro, Cancer Lett 293:31-40, 2010.

27. Kővári B, Rusz O, Schally AV, Kahán Z and Cserni G: Differential immunostaining of various types of breast carcinomas for growth hormone releasing hormone receptor Apocrine epithelium and carcinomas emerging as uniformly positive, APMIS 122:824831,2014

28. Halmos G, Schally AV, Czompoly T, Krupa M, Varga J and Rekasi Z: Expression of growth hormon relasing hormone and splice variants in human prostate cancer, $J$ Clin Endocrinol Metab 87:4707-4714, 2002.

29. Barabutis N, Siejka A, Schally AV, Block NL, Cai R and Varga JL: Activation of mitogenactivated protein kinases by a splice variant of GHRH receptor, J Mol Endocrinol 44:127-134, 2010.

30. Granata R, Trovato L, Gallo MP, Destefanis S, Settanni F, Scarlatti F, Brero A, Ramella R, Volante M, Isgaard J, Levi R, Papotti M, Alloatti G and Ghigo E: Growth hormonereleasing hormone promotes survival of cardiac myocytes in vitro and protects against ischaemia-reperfusion injury in rat heart, Cardiovasc Res 83:303-312, 2009.

31. Kanashiro-Takeuchi RM, Szalontay L, Schally AV, Takeuchi LM, Popovics P, Jaszberenyi M, Vidaurre I, Zarandi M, Cai RZ, Block NL, Hare JM and Rick FG: New therapeutic approach to heart failure due to myocardial infarction based on targeting growth hormone-releasing hormone receptor, Oncotarget 6:9728-39, 2015.

32. Penna C, Settanni F, Tullio F, Trovato L, Pagliaro P, Alloatti G, Ghigo E and Granata R: GH- 
releasing hormone induces cardioprotection in isolated male rat heart via activation of RISK and SAFE pathways, Endocrinology 154:1624-1635, 2013.

33. Kanashiro-Takeuchi RM, Takeuchi LM, Rick FG, Dulce R, Treuer AV, Florea V, Rodrigues CO, Paulino EC, Hatzistergos KE, Selem SM, Gonzalez DR, Block NL, Schally AV and Hare JM: Activation of growth hormone releasing hormone (GHRH) receptor stimulates cardiac reverse remodeling after myocardial infarction (MI), Proc Natl Acad Sci USA 109:559-563, 2011.

34. Cai R, Schally AV, Cui T, Szalontay L, Halmos G, Sha W, Kovacs M, Jaszberenyi M, He J, Rick FG, Popovics P, Kanashiro-Takeuchi RM, Hare JM, Block NL and Zarandi M: Synthesis of new potent agonistic analogs of growth hormone-releasing hormone (GHRH) and evaluation of their endocrine and cardiac activities, Peptides 52:104-112, 2014.

35. Kanashiro-Takeuchi RM, Tziomalos K, Takeuchi LM, Treuer AV, Lamirault G, Dulce R, Hurtado M, Song Y, Block NL, Rick F, Kulkovits A, Hu Q, Varga JL, Schally AV and Hare JM: Cardioprotective effects of growth hormone-releasing hormone agonist after myocardial infarction, Proc Natl Acad Sci USA 107:2604-2609, 2010.

36. Gorbe A, Giricz Z, Szunyog A, Csont T, Burley DS, Baxter GF and Ferdinandy P: Role of cGMP-PKG signaling in the protection of neonatal rat cardiac myocytes subjected to simulated ischemia/reoxygenation, Basic Res Cardiol 105: 643-650, 2010.

37. Szücs G, Murlasits Z, Török S, Kocsis GF, Pálóczi J, Görbe A, Csont T, Csonka C and Ferdinandy P: Cardioprotection by farnesol: role of the mevalonate pathway, Cardiovasc Drugs Ther 27:269-277, 2013.

38. Csonka C, Kupai K, Bencsik P, Görbe A, Pálóczi J, Zvara A, Puskas LG, Csont T and Ferdinandy P: Cholesterol-enriched diet inhibits cardioprotection by ATP-sensitive potassium channel activators cromakalim and diazoxide, Am J Physiol Heart Circ Physiol 
306:405-413, 2014.

39. Csont T, Bereczki E, Bencsik P, Fodor G, Görbe A, Zvara A, Csonka C, Puskás LG, Sántha $M$ and Ferdinandy P: Hypercholesterolemia increases myocardial oxidative and nitrosative stress thereby leading to cardiac dysfunction in apoB-100 transgenic mice, Cardiovasc Res 76:100-109, 2007.

40. Leprán I, Nemecz G, Koltai M and Szekeres L: Effect of linoleic acid-rich diet on the acute phase of coronary occlusion in conscious rats: Influence of indomethacin and aspirin, J Cardiovasc Pharmacol 3:847-53, 1981.

41. Kocsis GF, Sárközy M, Bencsik P, Pipicz M, Varga ZV, Pálóczi J, Csonka C, Ferdinandy P and Csont T: Preconditioning protects the heart in a prolonged uremic condition, Am $\mathrm{J}$ Physiol Heart Circ Physiol 303:1229-1236, 2012.

42. Sárközy M, Zvara A, Gyémánt N, Fekete V, Kocsis GF, Pipis J, Szücs G, Csonka C, Puskás LG, Ferdinandy $\mathrm{P}$ and Csont $\mathrm{T}$ : Metabolic syndrome influences cardiac gene expression pattern at the transcript level in male ZDF rats, Cardiovasc Diabetol 12:16, 2013.

43. Sharma S, Moros EG, Boerma M, Sridharan V, Han EY, Clarkson R, Hauer-Jensen M and Corry PM: A novel technique for image-guided local heart irradiation in the rat, Technol Cancer Res Treat 13:593-603, 2014.

44. Walker CM, Saldaña DA, Gladish GW, Dicks DL, Kicska G, Mitsumori LM and Reddy GP: Cardiac complications of oncologic therapy, Radiographics 33:1801-1815, 2013.

45. Adão R, de Keulenaer G, Leite-Moreira A and Brás-Silva C: Cardiotoxicity associated with cancer therapy: pathophysiology and prevention strategies, Rev Port Cardiol 32:395-409, 2013.

46. Boerma M: Experimental radiation-induced heart disease: past, present, and future, 
Radiat Res 178:1-6, 2012.

47. Salata C, Ferreira-Machado SC, De Andrade CB, Mencalha AL, Mandarim-De-Lacerda CA and de Almeida CE: Apoptosis induction of cardiomyocytes and subsequent fibrosis after irradiation and neoadjuvant chemotherapy, Int J Radiat Biol 90:284-290, 2014.

48. Rübe CE, Fricke A, Wendorf J, Stützel A, Kühne M, Ong MF, Lipp P and Rübe C: Accumulation of DNA double-strand breaks in normal tissues after fractionated irradiation, Int J Radiat Oncol Biol Phys 76:1206-1213, 2010.

49. Drigotas M, Affolter A, Mann WJ, Brieger J: Reactive oxygen species activation of MAPK pathway results in VEGF upregulation as an undesired irradiation response, $J$ Oral Pathol Med 42:612-619, 2013.

50. Abdel-Wahab M, Schally AV, Rick GF, Szalontay L, Block LN, Jorda M, Mahmoud O, Markoe A, Shi YF, Reiner T, Zarandi M and Duncan R: Antagonists of growth hormone releasing hormone (GHRH) given before whole body radiation lead to modulation of radiation response and organ-specific changes in the expression of angiogenesis, $J$ Radiat Oncol 1:389-396, 2012.

51. Kiscsatári L,Varga Z, Görbe A, Morvay N, Kővári B, Ferdinandy P, Leprán I, Kahán Zs: In vitro és in vivo állatmodellek a szív radiogén sugárkárosodásának vizsgálatára, Magyar Onkológia (Klsz) 57:114-135, 2013.

52. Kiscsatari L, Varga Z, Gorbe A, Morvay N, Kovari B, LepranI , Ferdinandy P, Kahan Z: P689 Examination of radiation-induced heart damage using in vitro and in vivo animal models, Cardiovascular Research 103:S102-S141, 2014.

53. Krüse JJ, Zurcher C, Strootman EG, Bart CI, Schlagwein N, Leer JW and Wondergem J: Structural changes in the auricles of the rat heart after local ionizing irradiation, Radiother Oncol 58:303-11, 2001. 
54. Seemann I, Gabriels K, Visser NL, Hoving S, te Poele JA, Pol JF, Gijbels MJ, Janssen BJ, van Leeuwen FW, Daemen MJ, Heeneman S and Stewart FA: Irradiation induced modest changes in murine cardiac function despite progressive structural damage to the myocardium and microvasculature, Radiother Oncol 103:143-50, 2012.

55. Ghobadi G, van der Veen S, Bartelds B, de Boer RA, Dickinson MG, de Jong JR, Faber H, Niemantsverdriet M, Brandenburg S, Berger RM, Langendijk JA, Coppes RP and van Luijk P: Physiological interaction of heart and lung in thoracic irradiation, Int $\mathrm{J}$ Radiat Oncol Biol Phys 84:639-46, 2012.

56. Adela R and Banerjee SK: GDF-15 as a Target and Biomarker for Diabetes and Cardiovascular Diseases: A Translational Prospective, J Diabetes Res 2015:490842, 2015.

57. Zhou YM, Li MJ, Zhou YL, Ma LL and Yi X: Growth differentiation factor-15 (GDF-15), novel biomarker for assessing atrial fibrosis in patients with atrial fibrillation and rheumatic heart disease, Int J Clin Exp Med 8:21201-7, 2015.

58. Sándor N, Schilling-Tóth B, Kis E, Fodor L, Mucsányi F, Sáfrány G and Hegyesi H: TP53inp1 Gene Is Implicated in Early Radiation Response in Human Fibroblast Cells, Int J Mol Sci 16:25450-65, 2015.

59. Sándor N, Schilling-Tóth B, Kis E, Benedek A, Lumniczky K, Sáfrány G and Hegyesi H: Growth Differentiation Factor-15 (GDF-15) is a potential marker of radiation response and radiation sensitivity, Mutat Res Genet Toxicol Environ Mutagen 793:142-9, 2015.

60. Kempf $\mathrm{T}$ and Wollert $\mathrm{KC}$ : Growth-differentiation factor-15 in heart failure, Heart Fail Clin 5:537-47, 2009.

61. Lok SI, Winkens B, Goldschmeding R, van Geffen AJ, Nous FM, van Kuik J, van der Weide P, Klöpping C, Kirkels JH, Lahpor JR, Doevendans PA, de Jonge N and de Weger RA: 
Circulating growth differentiation factor-15 correlates with myocardial fibrosis in patients with non-ischaemic dilated cardiomyopathy and decreases rapidly after left ventricular assist device support, Eur J Heart Fail 14:1249-56, 2012.

62. Andersson C, Enserro D, Sullivan L, Wang TJ, Januzzi JL Jr, Benjamin EJ, Vita JA, Hamburg NM, Larson MG, Mitchell GF and Vasan RS: Relations of circulating GDF-15, soluble ST2, and troponin-I concentrations with vascular function in the community: The Framingham Heart Study, Atherosclerosis 248:245-51, 2016.

63. Westbury CB and Yarnold JR: Radiation fibrosis--current clinical and therapeutic perspectives, Clin Oncol (R Coll Radiol) 24:657-72, 2012. 


\section{APPENDIX}

